\title{
Inclusive Streets for Fostering the Notion of Public Space
}

\author{
Ar. Bhagyalaxmi S Madapur ${ }^{1}$, Dr. Mamatha P Raj ${ }^{2}$ \\ ${ }^{1}$ B M S College of Architecture, Bull Temple Road, Basavanagudi, Bangalore, Karnataka, India \\ ${ }^{2}$ B M S College of Architecture, Bull Temple Road, Basavanagudi, Bangalore, Karnataka, India \\ *Bhagyalaxmi S Madapur
}

\begin{abstract}
:
"We go back to some streets more often than others...May be a street unlocks memories or offers expectations of something pleasant to be seen, or the possibility of meeting someone old or someone new...Because some streets are more pleasant than others, we go out of our way to be on them."
\end{abstract}

Allan B. Jacobs

Every city is experienced differently and leave varied impressions on the inhabitants. A city is defined by its public spaces of tangible nature which anchor socio-economic and cultural activities defining the unique dimensions of its community while giving an 'identity' and 'image' promoting social interaction vital for quality urban life.

These anchoring public spaces could range from an engaging street, plaza, market areas, a strip of active park, water front promenade to public buildings and socio-cultural districts within the public realm.

Among these public spaces, streets habitually form major components acting as public stages where life unfolds and belongingness is celebrated. They are more than just a means of mobility and weave intricately the diverse grains of urban fabric.

With the infringement of automobile oriented commuting, sweeping changes fueled by economic growth, increasing exclusivity of user groups, fading human scaled built forms and rapidly changing nature of social life, the streets which are the most visible parts of our urban commons often providing enriching experiences are being propelled sideways.

There is a need to understand and analyze the spatial forces and social encounters that shape street experiences at various scales and layers of the city so that the streets reconfigure themselves into more contextually inclusive in nature through which one perceives the city of the contemporary era.

In this context, this paper primarily aims to study and analyze various challenges faced by Indian streets using Gandhi Bazaar, a significant street in the historic precinct of Basavanagudi area of Bangalore metropolis as a case study. The analysis intends to explore how inclusive design strategies and approaches accentuate better use of existing public space through optimum space management and time based sharing thus supplementing in crafting resourceful use of public space for diverse stakeholders.

Key Words: Inclusive street, Public space, Public realm, Commuting, Social interaction 


\section{Introduction}

Cities are defined by their public spaces that anchor socio-economic and cultural activities defining the unique dimensions of its community often providing enriching experiences. Public spaces being urban elements reinforce the different components of the urban fabric. Connotations of public space are always the blue print reflecting the context, culture and temporal variations. Most often public spaces evolve organically over a time period or may be planned and managed by public sector and in some cases private sector but open to public. Public spaces being soul of a community, renders 'identity' and 'sense of place' while promoting social interaction which is vital for quality urban life. These anchoring tangible public spaces with intangible qualities range from an engaging urban street, sidewalks, plaza, boulevards, market areas, a strip of active park, lakes, water front promenade to public buildings and socio-cultural districts within the public realm creating liveable communities. Urban sprawl is reconfiguring the notion of physical public spaces to encompass the omnipresent digital technologies (Information and Communication Technologies) surround everyday life of urban dwellers constantly adding a digital layer on the existing urban landscape creating physical and virtual public spaces. Contemporary socio-political systems as they affect cities, tend to encourage privatization of public spaces often leading to conflicts among various stakeholders and interest groups.

Figure 1,2 \& 3: Public Spaces: Streets, Market Places and Open - green spaces
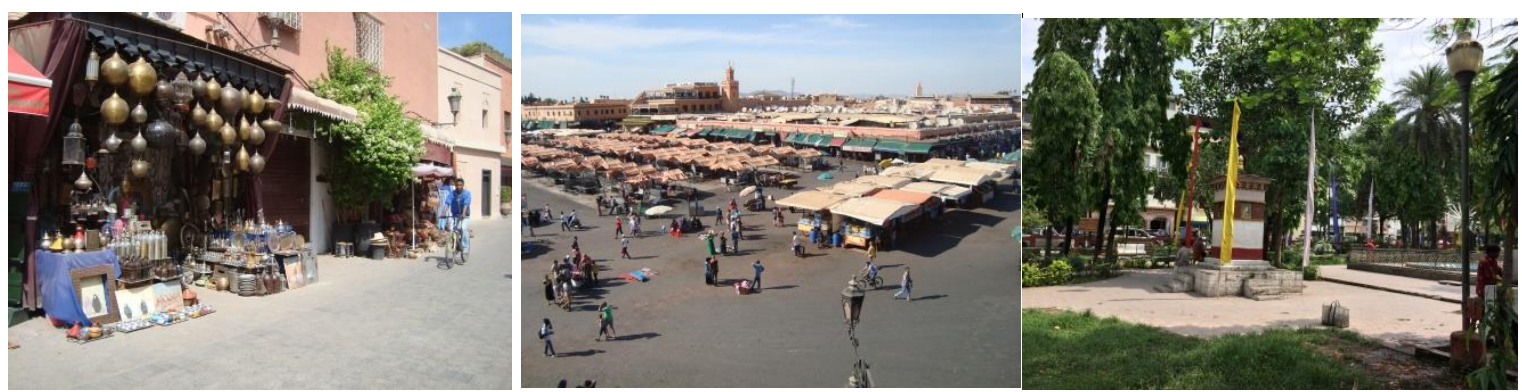

Source: Authors

Urban streets forming the prime composition of the public space, in its symbolic and physical facet address not only functional adoptions, but is a decisive factor performing a key role in promoting progressive urban culture. Physical and social dynamics of a street capitalizes on the community's deeply valued connectedness in the everyday urban life. Wellarticulated urban streets empower communities that contain them by fostering positive social encounters.

\section{Urban Roads or Urban Streets - Changing Facets of Paths of Crusade}

Streets and their patterns, by themselves or in relation to each other bring comprehension to the city. Differences in terms of spaces, scale, complexity and choices available are reflected beyond the street patterns. Streets are defined in two ways: vertically which has to do with height of buildings or walls or trees along a street; and horizontally which has most to do with the length of and spacing between whatever is doing the defining.

Urban streets are inherently multi-dimensional and related attributions particularly sensitive to the physical character of the built environment influencing the perceptions of the urban dwellers (Refer Table 1). 
Table 1: Multi-dimensional attributions of urban streets

\begin{tabular}{|c|c|c|}
\hline Sl. NO. & DIMENSION & ATTRIBUTES \\
\hline 1 & $\begin{array}{c}\text { Sense of community and } \\
\text { belongingness }\end{array}$ & $\begin{array}{ll}\text { - } & \text { Fosters social interaction } \\
\text { - } & \text { Better environmental quality } \\
\text { - } & \text { physider social inclusion and accessibility (spatial and } \\
\text { - } & \text { Greater cultural pluralism } \\
\text { - } & \text { gerceived notion of safety for people of all ages and } \\
\text { - } & \text { Community involvement }\end{array}$ \\
\hline 2 & Supports local economy & $\begin{array}{l}\text { - Varied entrepreneurship opportunities } \\
\text { - } \quad \text { Enhanced economies, tax revenues and market values }\end{array}$ \\
\hline 3 & Promotes public health & $\begin{array}{l}\text { - Promotes use of active transport - walking /cycling } \\
\text { - Compatible with public transit leading to better } \\
\text { connectivity }\end{array}$ \\
\hline
\end{tabular}

Source: Authors

\section{Bangalore City - Mapping the Morphology of public spaces}

Over the past seventy years, Bangalore, the capital city of Karnataka state in India famously referred as Silicon Valley of India has morphed from being a non-descript town into the most cosmopolitan metropolis (Refer Fig. 4). The transformation of the city has been exceptionally marked by several phases of investments and developments in various socioeconomic sectors (public and private), remarkable demographic growth as well as flourishing informal economy.

In Bangalore, two typological variations of public spaces, streets and squares have been one of the primary podiums to express a sense of belonging and ownership. However, swift transformation has been fueling unregulated development and consequently encroachment of public spaces such as streets, traditional markets, city squares, public parks, open as well as green spaces that represent a community's soul. Furthermore, diverse characteristics of omnipresent ICTs (Information and Communication Technologies) are re-shaping the cognition and social organization. Traditional mass media communication has changed dramatically and has been evolving into 'personal communication societies of super connected citizens. It is contributing to a number of socio-economic consequences including new representations of self, social networks and 'private use of public space'.

Fig. 4: Location of Bangalore with respect to India and Karnataka state

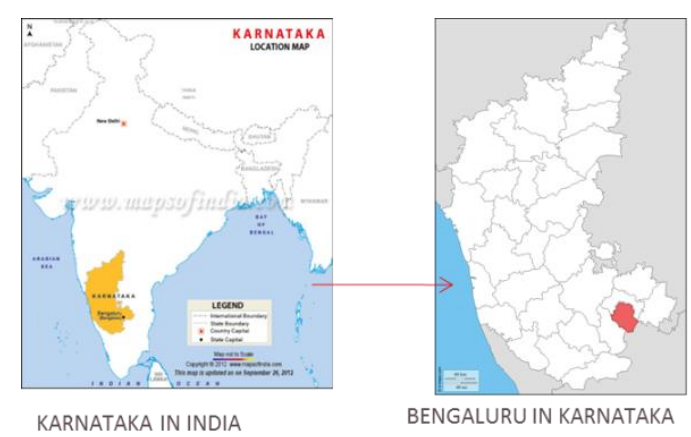

Source: Maps of India \& edited by the authors 
In the nineteenth century, Bangalore comprised of two cities, Pete (Indian City) and the Cantonment (Colonial city) that had evolved into different urban forms and thus developing their own configurations of public spaces. Various elements rendered imageability to the public spaces of both the cities (Refer Table 2).

Table 2: Various elements rendering imageability of public spaces in Pete and Cantonment

\begin{tabular}{|c|l|l|}
\hline Elements & \multicolumn{1}{|c|}{ Pete (Indian City) } & Cantonment (Colonial city) \\
\hline Urban Structure & $\begin{array}{l}\text { Close knit urban fabric with narrow } \\
\text { meandering street pattern focused on } \\
\text { pedestrians with narrow plots. }\end{array}$ & $\begin{array}{l}\text { Cantonment developed wide } \\
\text { tree-lined street patterns } \\
\text { mainly for vehicular traffic } \\
\text { and spacious plots. }\end{array}$ \\
\hline Urban Form & $\begin{array}{l}\text { Medieval planning concept: High } \\
\text { density, close knit and mixed use } \\
\text { neighborhoods. }\end{array}$ & $\begin{array}{l}\text { Garden city planning concept: } \\
\text { Low density and functional } \\
\text { zoning based neighborhoods. }\end{array}$ \\
\hline Public spaces & $\begin{array}{l}\text { Temple squares and markets (daily / } \\
\text { weekly/ seasonal) forming the nodes of } \\
\text { public spaces. }\end{array}$ & $\begin{array}{l}\text { Parks, parade grounds, clubs, } \\
\text { shopping complexes, etc. } \\
\text { were few of the public spaces. }\end{array}$ \\
\hline
\end{tabular}

Source: Authors

\subsection{Streets - Linear public Spaces}

Streets have always been sought after prime public spaces in Bangalore supporting numerous activities be it social, economic or purely for cultural / religious festivities. It is used as a place often as temporary or permanent place to vend, work, live, socialize, recreation, manufacture, and provide services. Several examples such as Gandhi Bazaar Main Road, Bull Temple Road, Brigade Road, M G Road, B.V.K. Iyengar Road, Avenue Road, Sampige Road, Commercial Street, V V Puram's Eat Street, etc. stand as testimonials to the usage of streets as significant public spaces for diverse activities.

Fig. 5, 6, 7 \& 8: Bangalore's linear public spaces in different settings
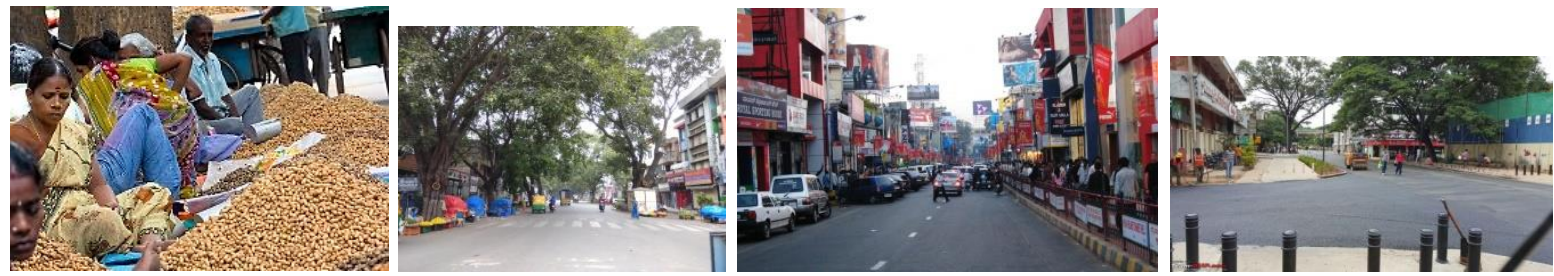

Source: Authors

\subsection{Deteriorating Quality of Streets as Public Spaces}

The semi-private realm is being engaged by the heterogeneous spaces that are being built owing to the global city image of Bangalore resulting in diminishing public realm. It's been constantly confronting several issues with regard to its public spaces; absence of iconic public spaces as major landmarks representing the cityscape and the privatization of public spaces are the crucial ones. The size and heterogeneity of the Bangalore city and its neighborhoods, affects the balance between private and public realm forcing urban dwellers to withdrawal into their private realms discounting the incentive conveyed by physical public spaces. 
Unregulated development and the resulting congestion, surge in population, density, jostle for space, vehicular pressure, encroachment of sidewalks, and lack of implementation authorities for the management of public spaces have been steadily contributing to the deteriorating quality of streets as public spaces. This particular trend draws attention to the need for a re-evaluation of the street's functioning to explore reconfigured spatial types of public spaces in turn lending much required imageability and inclusivity (both spatially and socially) to the capital city. Physical, cultural, political, technological and economic factors have been greatly impacting the social and symbolic public life of Bangaloreans. The street is losing its value as a public space as city authorities are increasingly converting the boulevards and avenues to major arterial roads reducing the streets to the mere circulation function.

Fig. 9 \& 10: Deteriorating Quality of Streets as Public Spaces
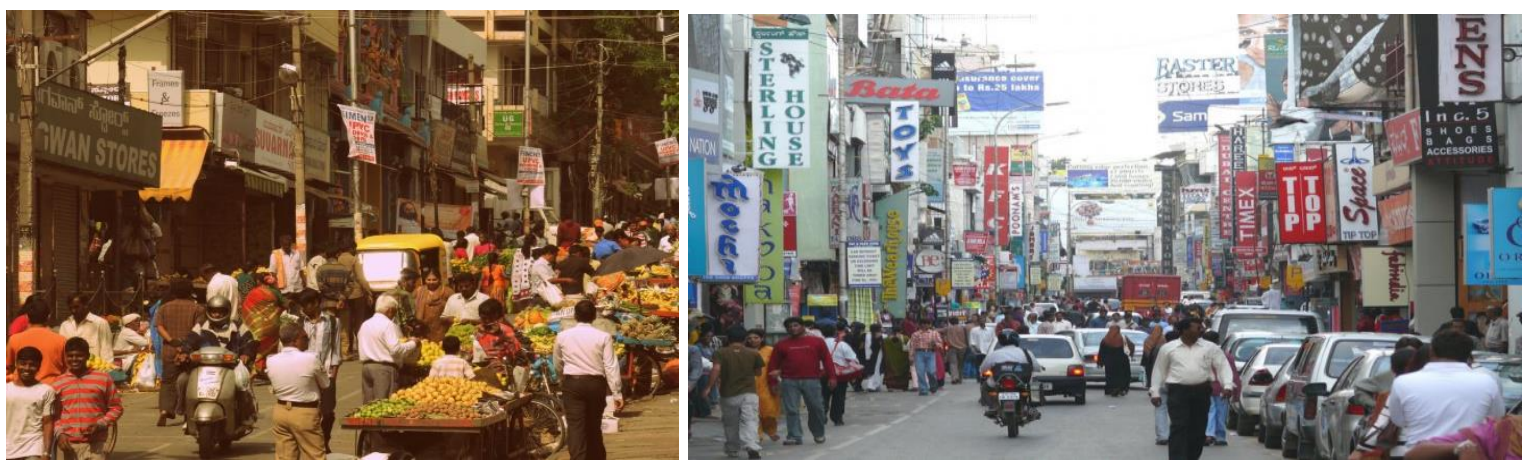

Source: Authors

In this context, the study attempts to analyze various challenges faced by Gandhi Bazaar Main Road, a significant street in the historic precinct of Basavanagudi area of Bangalore metropolis as a case study. The analysis intends to explore how inclusive design strategies and approaches to accentuate better use of existing public space through optimum space management and time based sharing thus supplementing in crafting resourceful use of public space for diverse stakeholders.

\section{Basavanagudi Neighbourhood}

Basavanagudi is one of the oldest and historically significant areas of growing metropolitan city of Bangalore. It is named after a huge temple dedicated to bull (Basavanagudi) which is a major religious landmark on the cultural map of Bangalore. A major epidemic, plague in 1898, forced city administrators to enforce the rules of town planning that emphasized on public health. Basavanagudi was the location of the plague camp. But soon an extension in the form of a layout was planned on 440 acres of dry land and came to be popularly known as Basavanagudi built strictly according to the grid iron or chess plan and were promoted as 'Model Hygienic Suburbs'.

Basavanagudi extension facilitated built forms to be constructed facing the cardinal points as per the ancient Indian planning principles by following the rectangular design, with boundary roads running North-South and East-West and intermediate roads parallel to them to them (Refer Fig.11). 


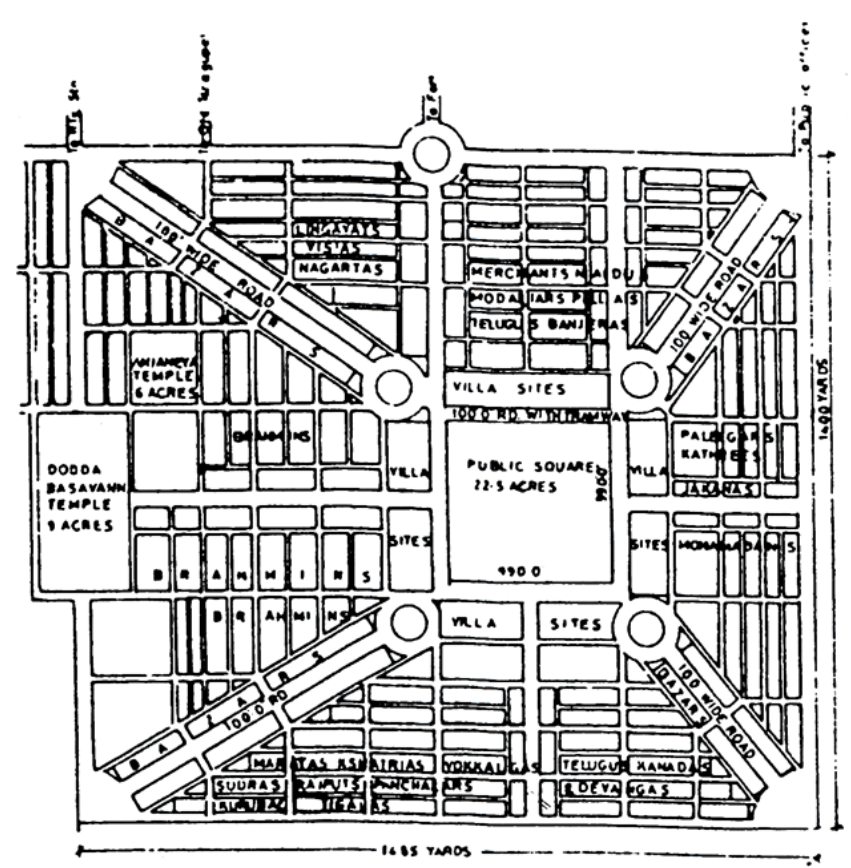

Source: Revenue Maps, Bangalore

\subsection{Gandhi Bazaar Main Road: A Street you go to, not just through}

Gandhi Bazaar having its own identity and unique features is a main road located in Basavanagudi, one of the oldest and historically significant areas of growing metropolitan city of Bangalore. It was named after Mahatma Gandhi to commemorate the historic march he took from Lalbagh botanical gardens to National College during the independence movement of India (Refer Fig.12 \& 13). The people, language, festivities and the cuisine are key aspects that render Gandhi Bazaar as a 'Melting pot of Culture'.
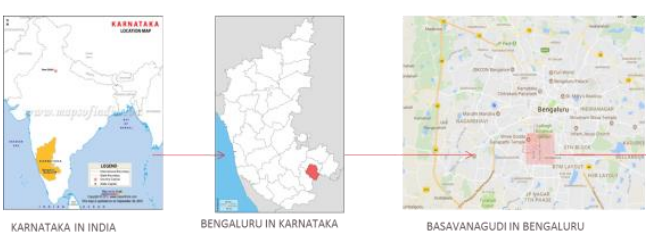

Source: Google Maps\& edited by authors
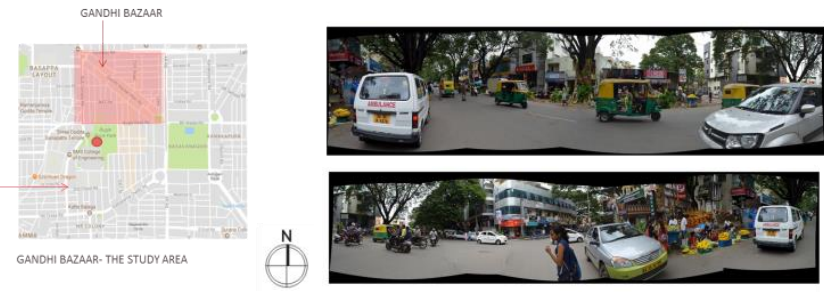

Source: Authors

At present under the pressure of unregulated transformation and tremendous growth, Gandhi Bazaar is turning into highly dense, congested, polluted and chaotic public place placing significant strain on the neighborhood fabric. Using it as a public place for numerous activities is getting frenzied day after day.

Against this background, Gandhi Bazaar Area has been studied and analyzed under different categories to address the issues of land use reconfiguration, street pattern and circulation, public realm and street edges, imageability, contest for public space and 
congestion. For the better comprehension, the study area has been divided into three major parts (Refer Fig. 14).

Fig. 14: Demarcation of study area into three major parts

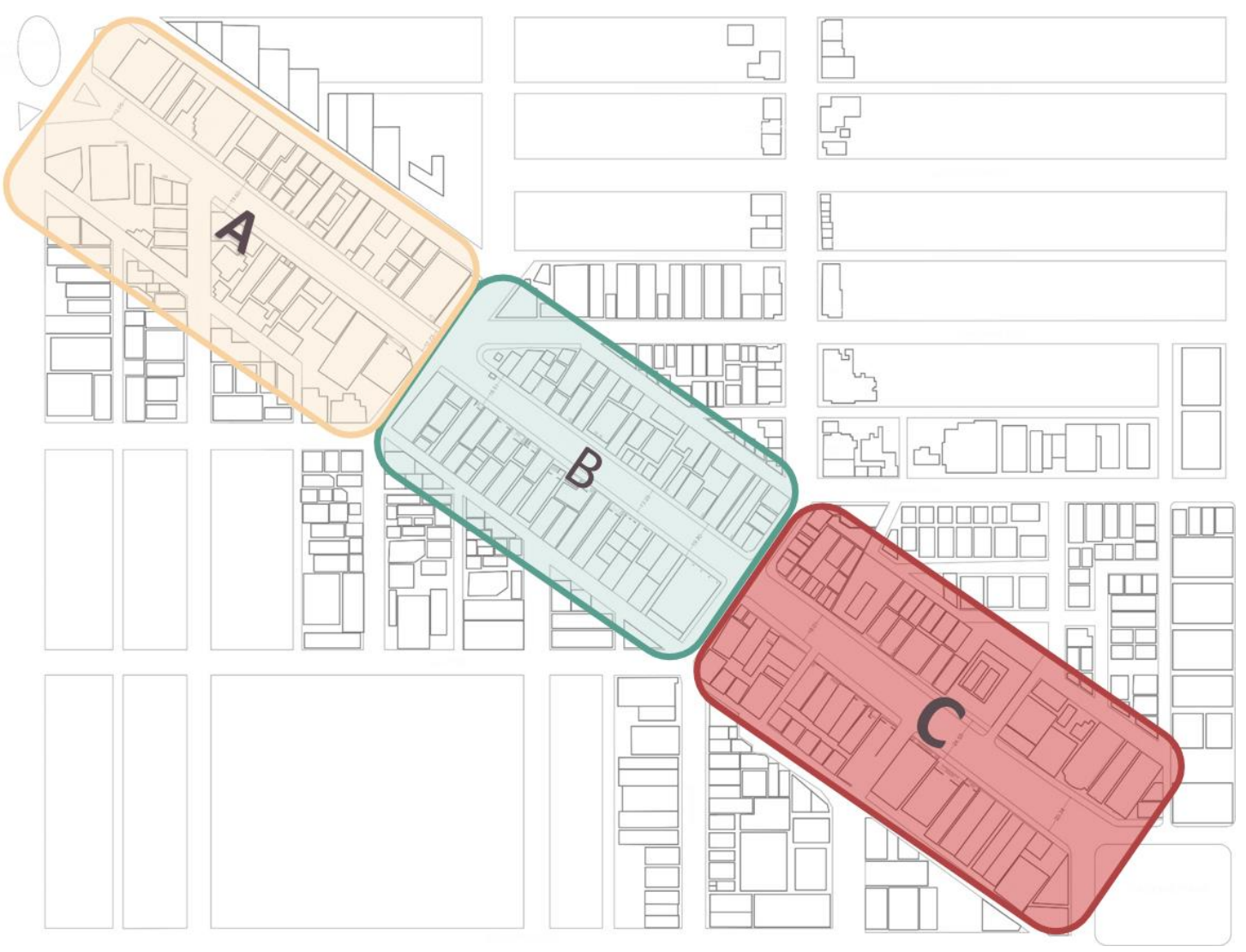

Source: Authors

Fig. 15: Transformation of built forms to suit contemporary necessities

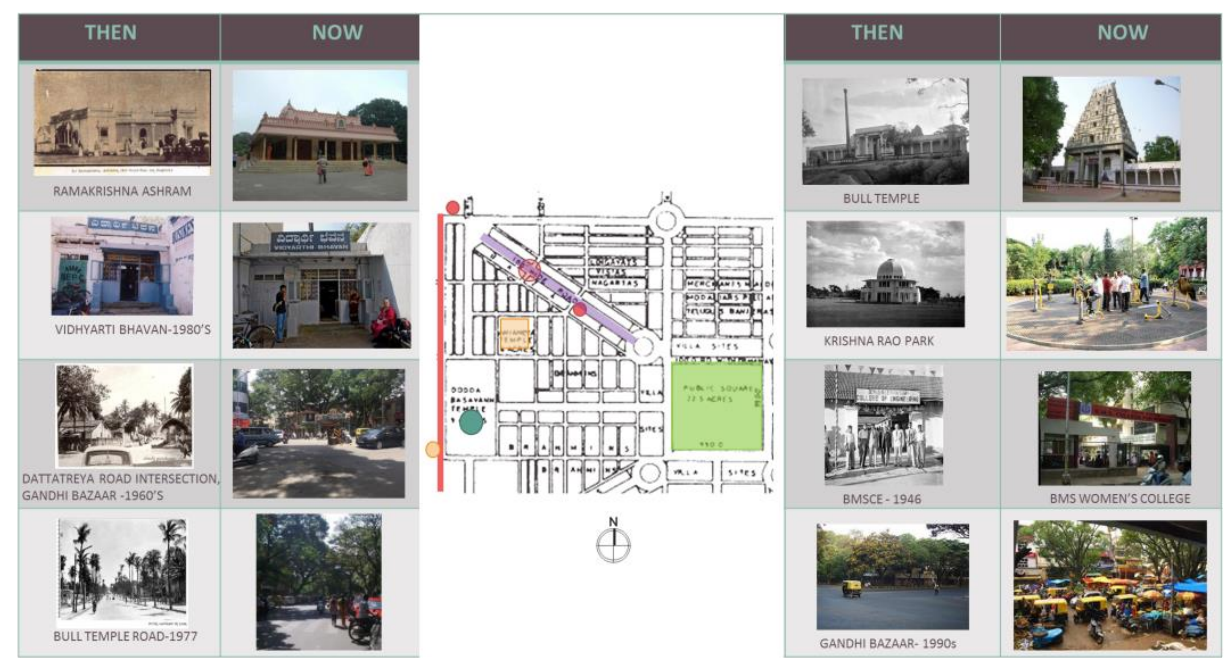

Source: Authors 


\subsubsection{Land use reconfiguration}

The major land use in the diagonal bazaar is commercial (mainly shops, retail stores and cafés), while the inner neighborhood is predominantly residential. The residential development is gradually rezoned into mixed use (residence \& retail shops or commercial \& public or commercial \& residential).

Fig. 15: Transformation of built forms to suit contemporary necessities

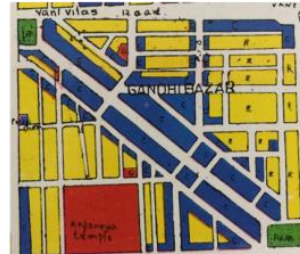

CDP 1995

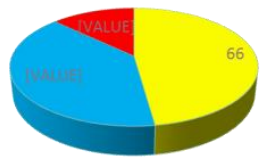

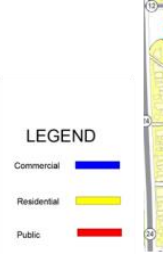

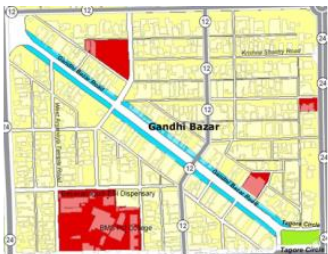

CDP 2015

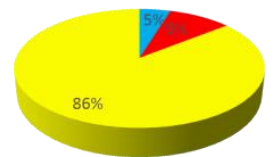

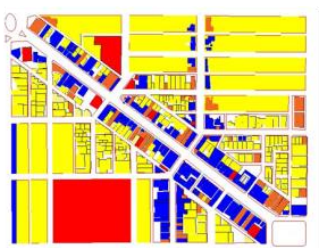

EXISTING

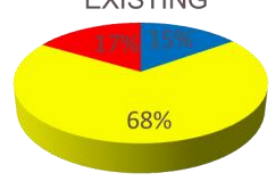

Source: BDA and edited by authors

\subsubsection{Built to Void Relationship}

A figure ground diagram allows for clear articulation of urban spaces and the connecting elements to link these spaces. The prime location of land has led to mixed used development of larger foot prints transforming the urban grain from cohesive fine grain (which responds to human scale) to coarse. The buildings are increasingly getting denser over the years due to the strategic location of the area and increase in land value. Figure ground here clearly indicates two distinct typologies of urban void: streets as linear grids and large open spaces as the temple premises, playgrounds and parks (Refer Fig. 16).

Fig. 16: Map showing built to void map

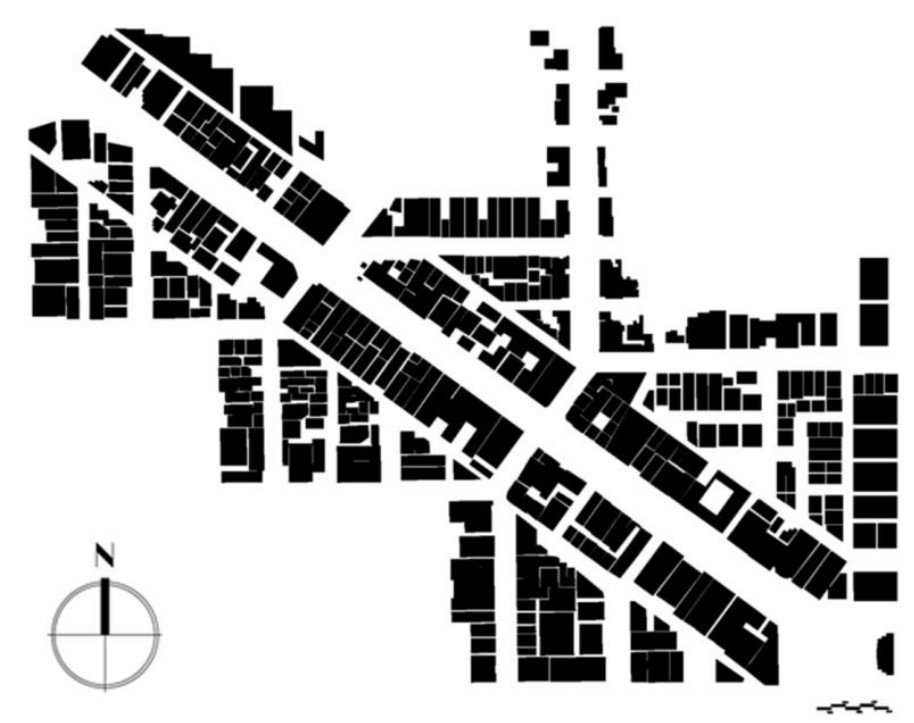




\subsubsection{Public Realm and Street Edge Conditions}

Street pattern and typologies of it forms the main guiding template in shaping the physical layout of an area or neighborhood having major impact on the accessibility criteria. Basavanagudi Extension Plan, 1894 (Refer Fig11) specifically indicates the prominence given to pedestrians through its street hierarchy to promote walkability of the neighborhood. Earlier streets had 8.0M wide footpaths (Refer Fig.8) which now range between1.15M to 3.9M (most of these shrunk footpaths are occupied by vendors and parked vehicles) owing to uncontrolled growth and increased vehicle density (Refer Fig.17).

Fig. 17: Map showing built to void map

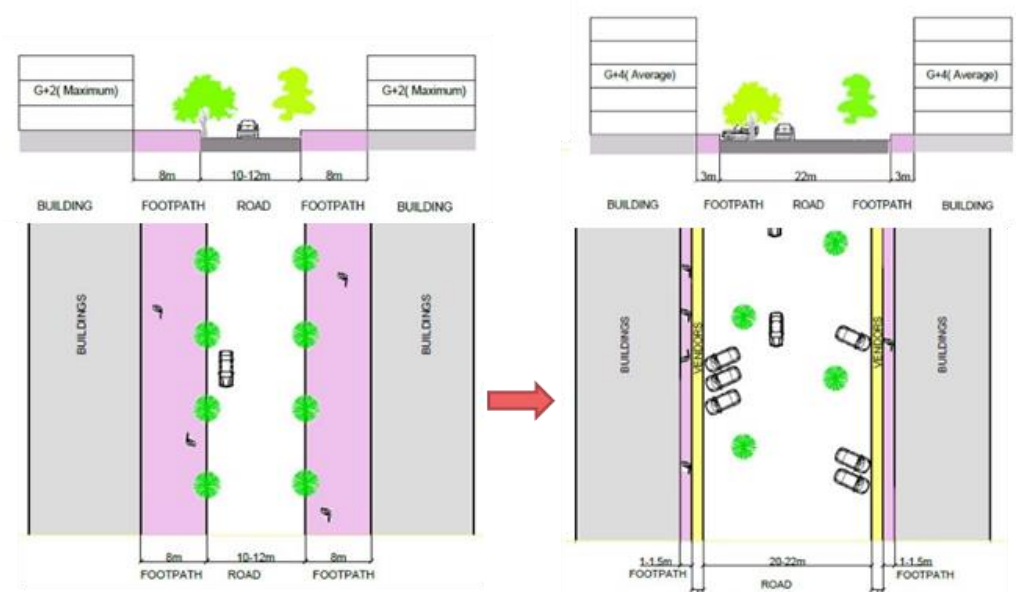

Source: Authors

The area is well connected by different street hierarchies and public transportation facilities within walkable distances (Refer Fig.18 \&19 respectively). The bus route is unidirectional along the Gandhi bazaar main road from Tagore circle to Ramakrishna ashram circle. The metro is also in the close proximity to the market, making it convenient for people of Bangalore to commute to the area. Gandhi bazaar being the famous historic destination for several activities, attracts of traffic both masses and vehicular.

Fig. 17: Map showing different road hierarchies

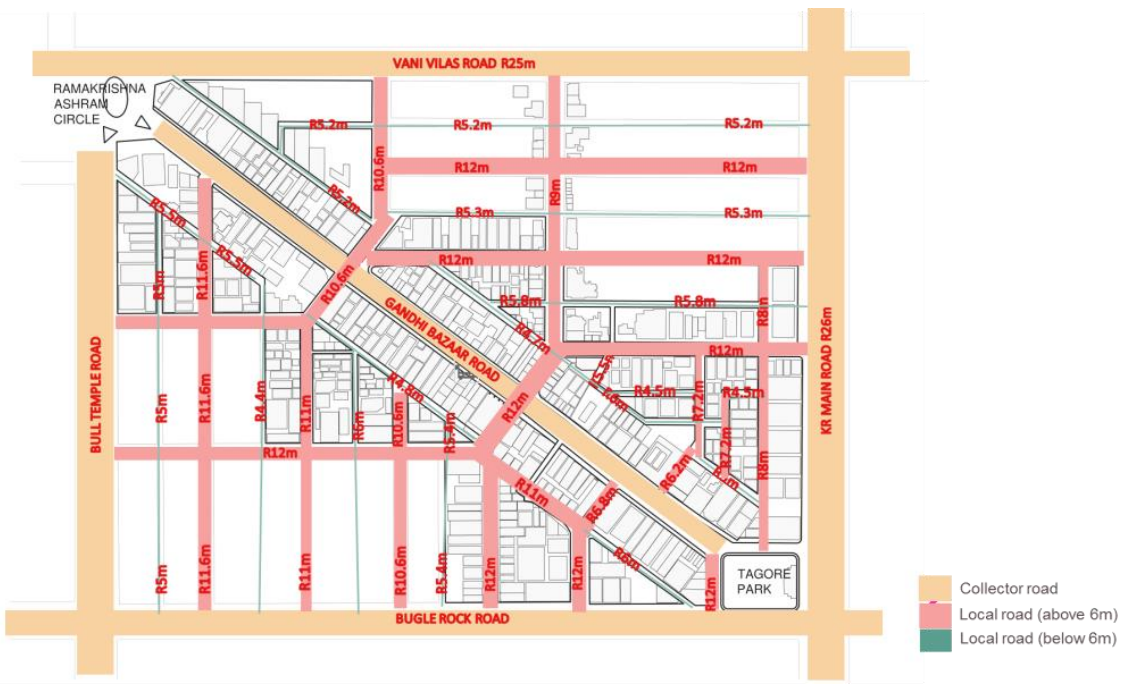

Source: Authors 
Fig. 17: Map showing major traffic movement along with bus stop locations and walkability radius

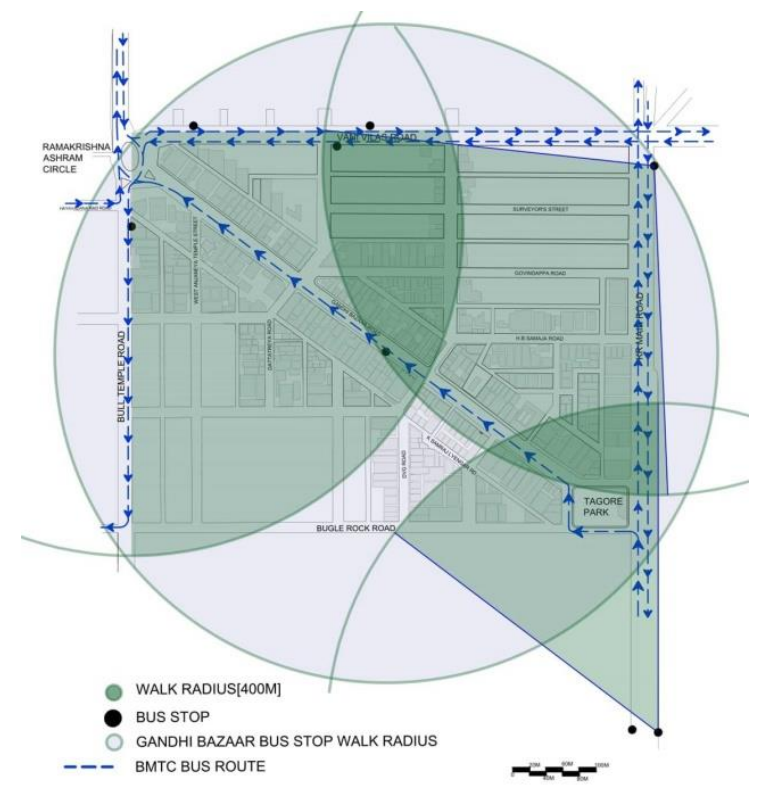

Source: Authors

The encroachment by the vendors makes it difficult for the pedestrians to walk on footpath. The pavements are narrow and not maintained properly. On - street unauthorized parking leads to the traffic jams and makes walking for pedestrians difficult especially during peak hours and festival days. The area needs better pedestrian infrastructure and streetscape facilities to augment the active transport (walkability and cycling) which is widely contemplated as one of the major decisive factor in enhancing public health and better quality of urban environment (Refer Fig.18).

Fig. 18: Series of pictures showing reduced width of footpaths

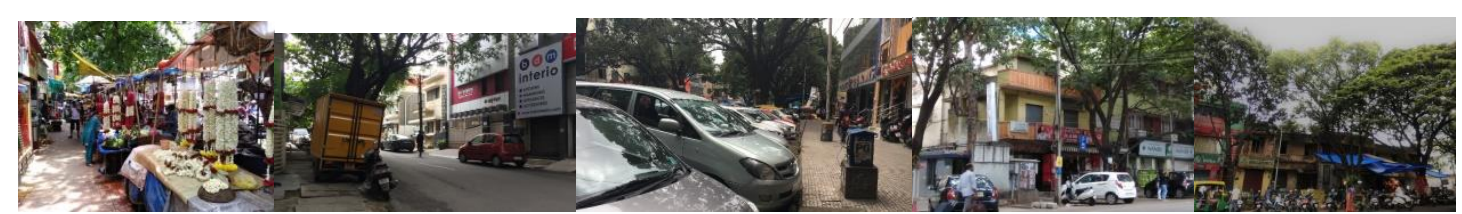

Source: Authors

Public realm, essentially representing the integral part of shared community space influences form and function of the neighborhoods. The current development of built environment is excluding the user group there by creating inappropriate and meaningless spaces. Thousands of people traverse through the area on daily basis for diverse activities (Refer Fig.19).

Fig. 17: Map showing major traffic movement along with bus stop locations and walkability radius

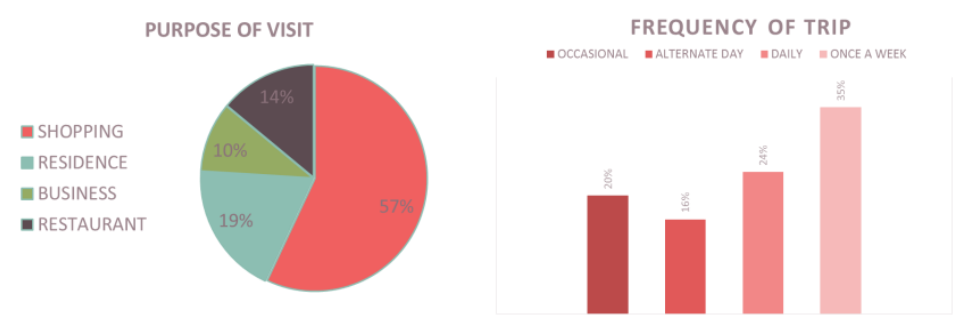

Source: Authors 


\subsubsection{Building Façade: Imageability and accessibility}

The process of building the imageability of an environment is undoubtedly the result of an interaction between the observer and the environment influencing mutually. Continuity is essential in creating imageability and experience. Comprehendible and interrelated built environments foster imageability of a space. The building facades are disordered and discontinuous as they lack any type of architectural language. The survey conducted revealed that on goers find only $17 \%$ building as attractive and almost $41 \%$ buildings as unattractive (Refer Fig.18, 19 \& 20).

Fig. 18: On goers perspective on façade quality of buildings

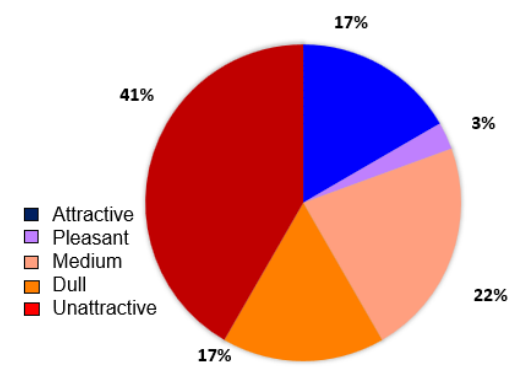

Source: Authors

Fig. 19: On goers perspective on façade quality of buildings

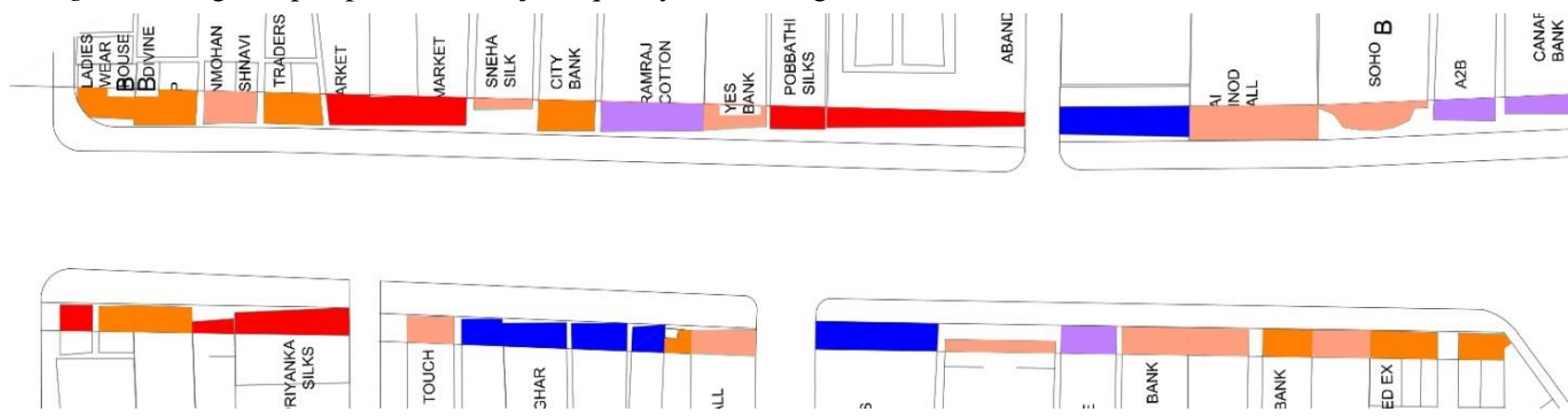

Source: Authors

Visual clues always do not communicate the fine difference between public and private which are either generally or selectively accessible. The assorted and active environment of the area provides comfort to the pedestrians on any day. The neighbourhood and especially the Gandhi Bazaar Street is largely seen as a place of transition rather than a place to pause or to be as it majorly lacks well-articulated spaces for social interactions (Refer Fig.20).

Fig. 20: Images showing lack of communication between public and private
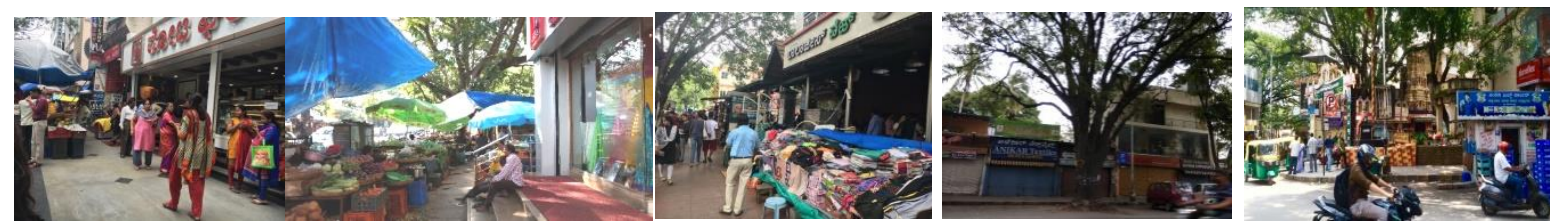

Source: Authors 
Fig. 21: Non-cohesive streetscape

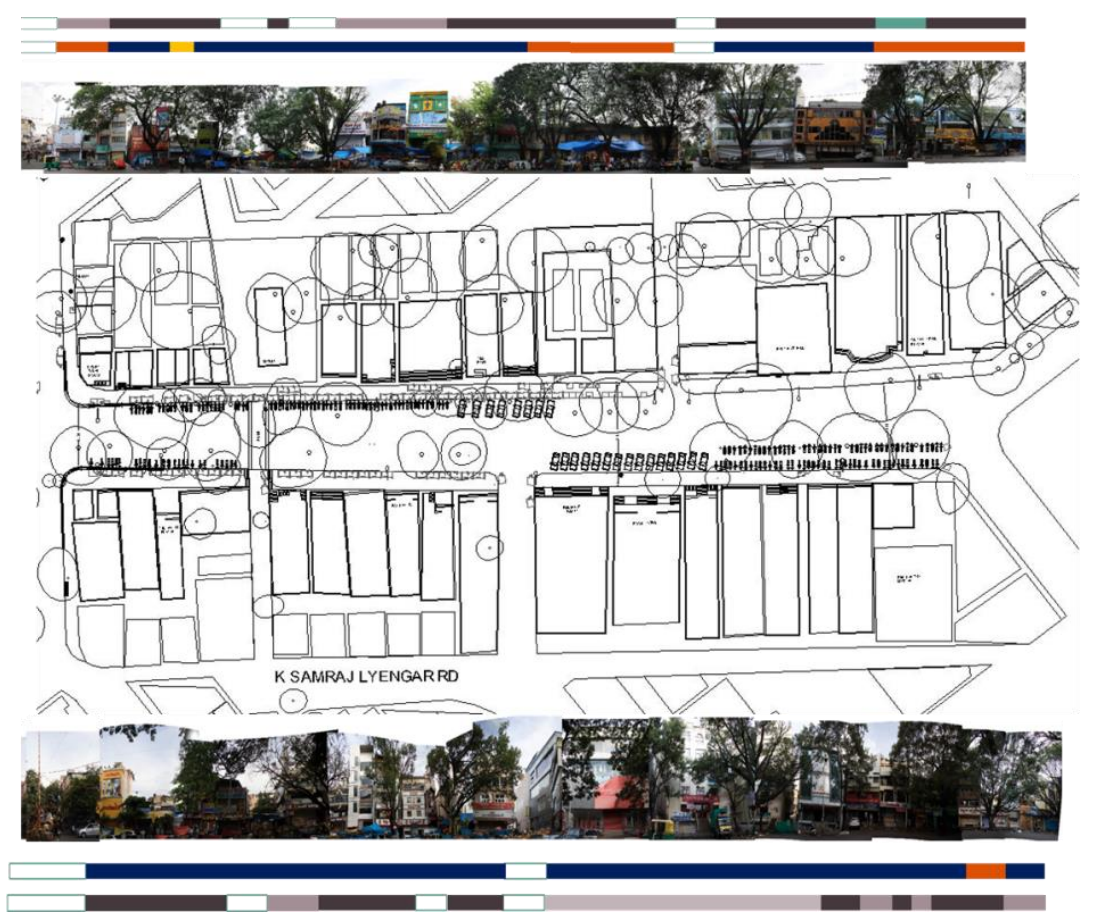

Building Use:

Commercial

Public / Semi Public

Residential

Mixed Use

Building Permeability:

Plinth Leve

Step Up, Step Down

Step Up, Ramp Down

No Entry Point

Source: Authors

Fig. 21, 22, 23, 24 \& 25: Street edge and public realm at Part-A of the study area
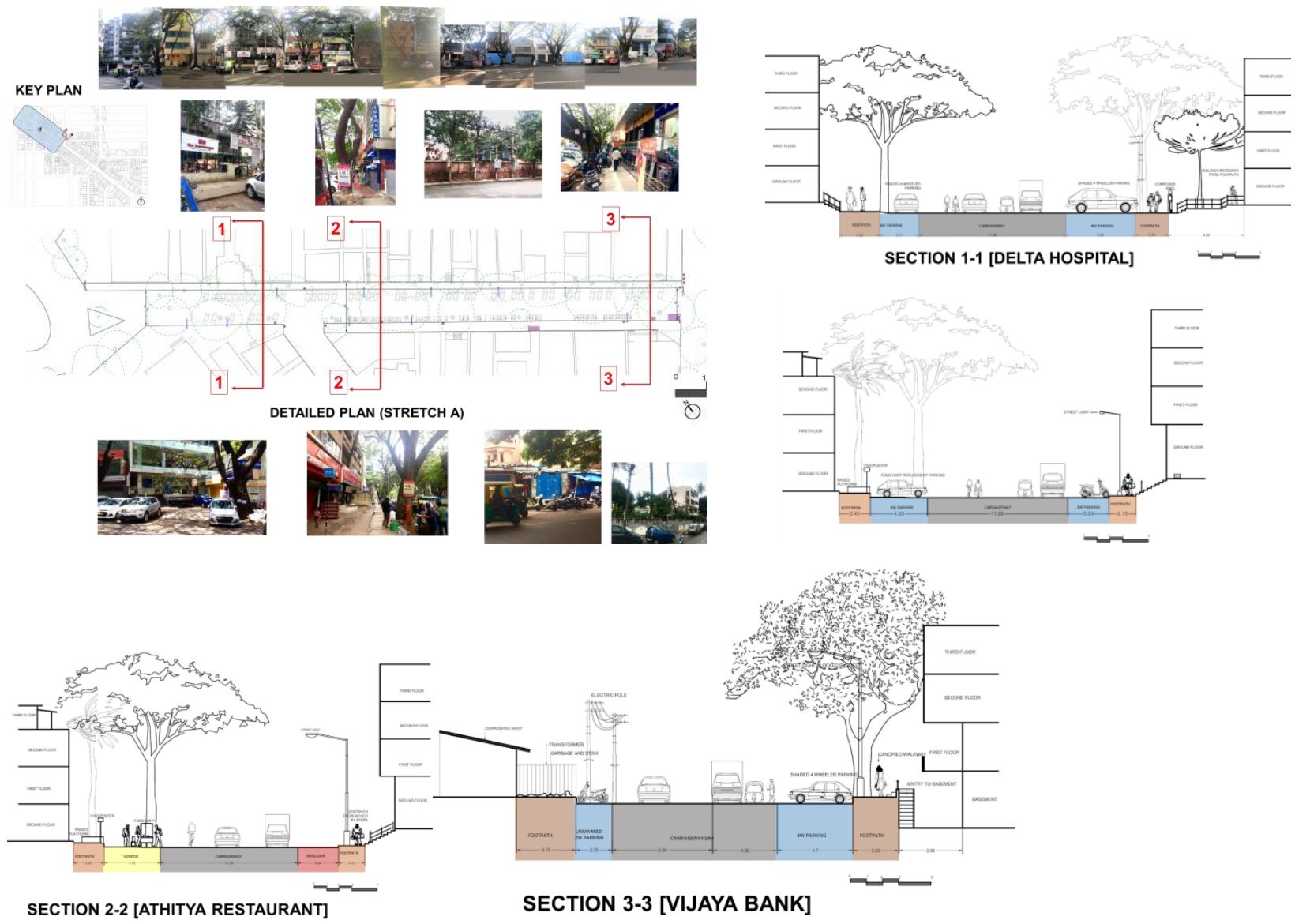

Source: Authors 
Fig. 24, 2526 \& 27: Street edge and public realm at Part-B of the study area

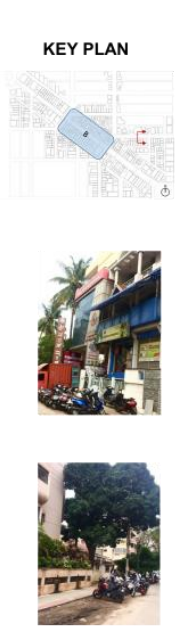

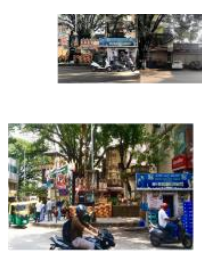
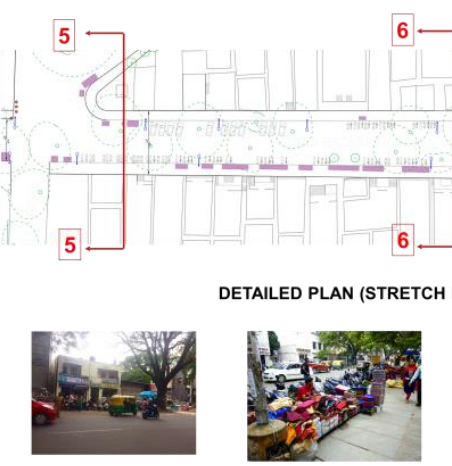

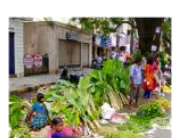

6
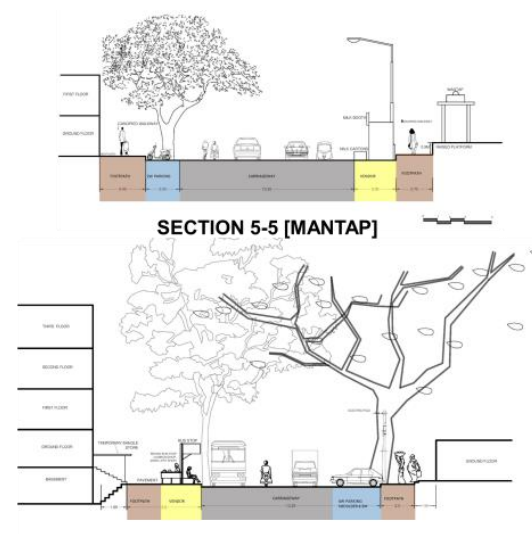

SECTION 6-6 [BUS STOP]

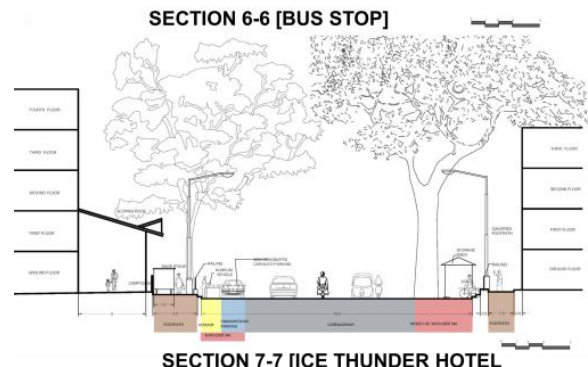

Source: Authors

Fig. 28, 2930 \& 31: Street edge and public realm at Part- $C$ of the study area
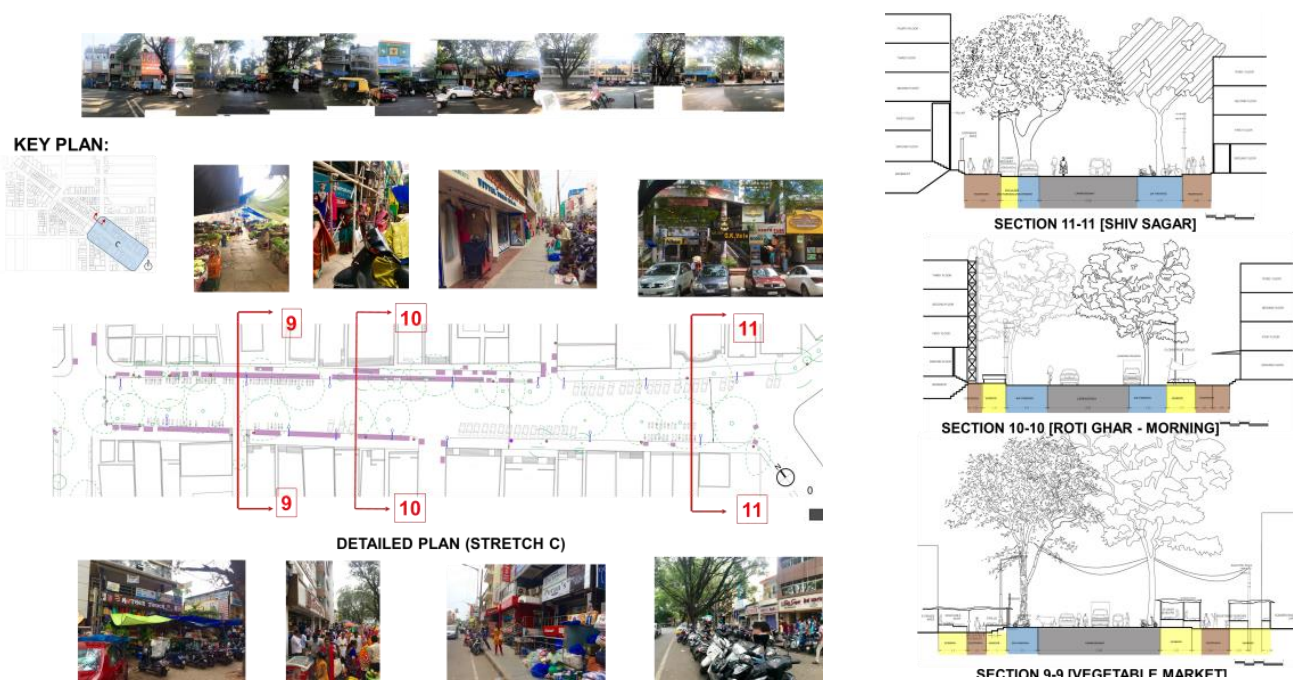

Source: Authors

Fig. 32: Images showing encroached footpaths
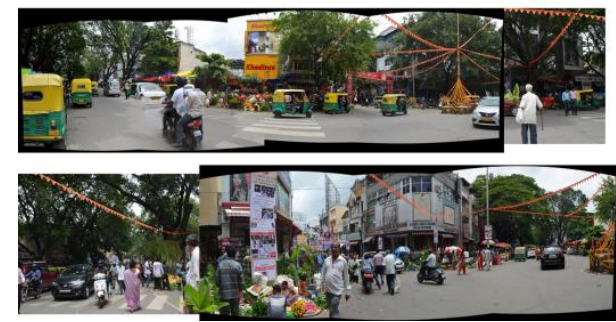

Source: Authors
Fig. 33: User density profile - Temporal variations

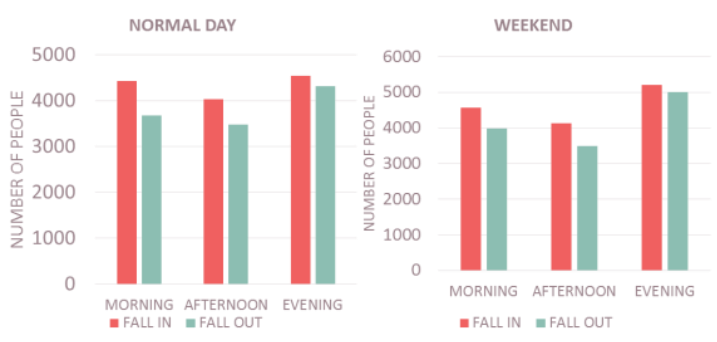

Source: Authors 
Street lights illuminate an elliptical area and cover a maximum intensity of $9 \mathrm{M}$ dia. Most of the trees are obstructing the light from the streetlights. Some lights are also very high to light the footpath.

Fig. 34 \& 35: User density profile - Temporal variations
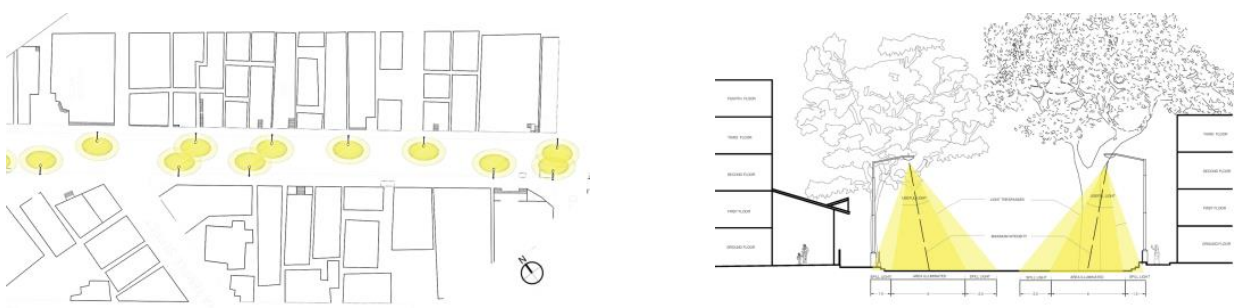

Source: Authors

\subsubsection{Green/ Open Spaces}

Urban open and green spaces include open spaces, sports fields, edges of roadway/railway/waterways, parks, botanical gardens, patches of vegetation, etc. The study area along with linear greenway (series of trees) has two famous neighbourhood parks. Mahogany, Rain tree and Gulmohar trees are prominent trees along with few other native species. The wide spread of canopy and green spaces of the area are home to local flora and fauna (Refer Fig. 36\&37).

Fig. 36\& 37: Maps showing the types and location of trees
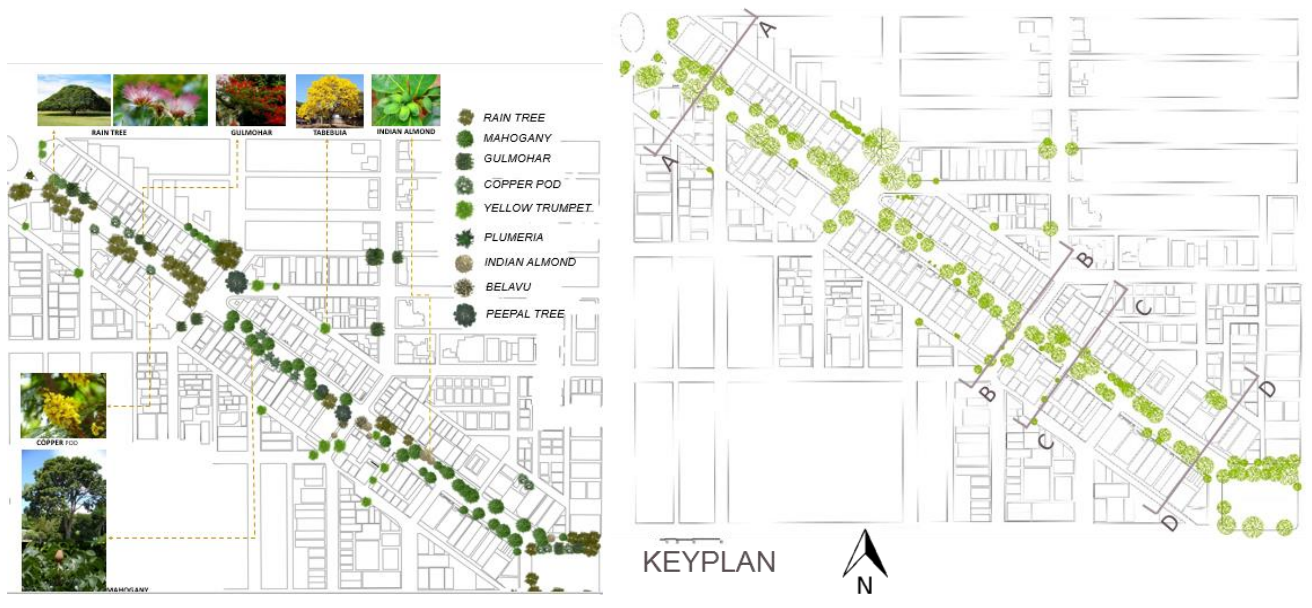

Fig. 38, 39\& 40: Sections and views showing the types and location of trees
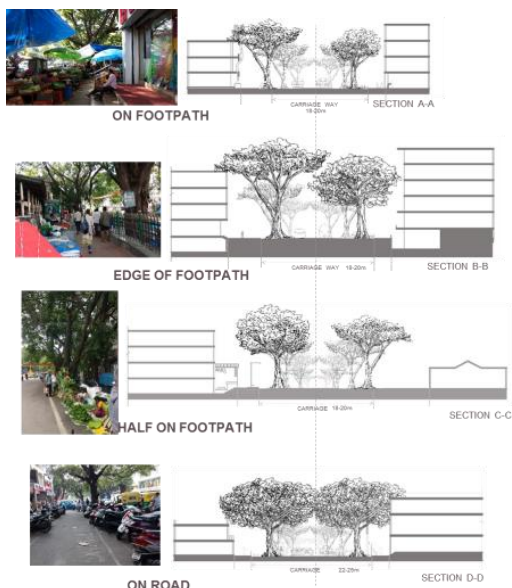

Source: Authors

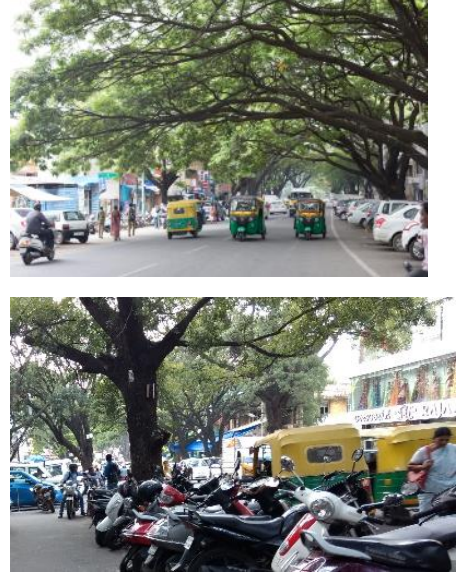




\subsubsection{Users Profile- Inhabitants and vendors}

Density, connectivity and fine grained land use diversity factors strongly influence the diverse user group. The density of users in an urban area is the result of the conditions of the built environment. The temporal distribution and patterns of the number of user group are closely linked to the dynamism of the area and may enhance the experiential quality by providing increased chances of interaction (direct and indirect) with other people and activities.

The study area is frequented by diverse users for generic and specific purposes and temporal variations do occur at different periods of time (Refer Fig. $41 \& 42$ ).

Fig. 41 Frequented locations of users

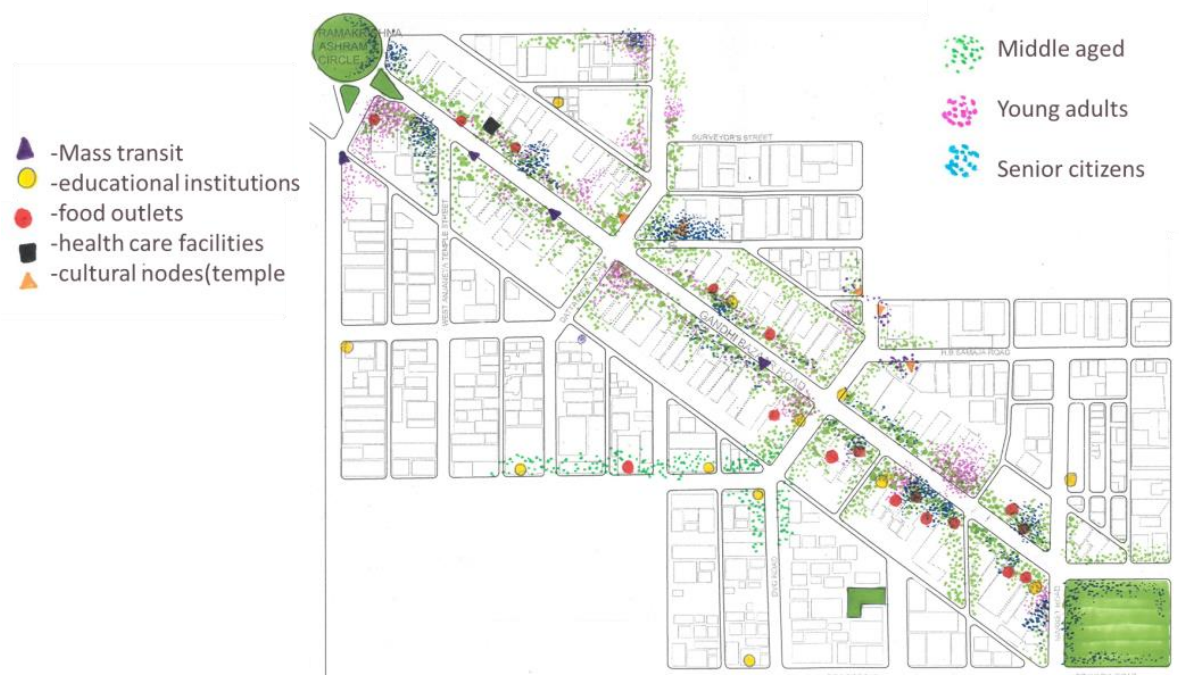

Fig. 42 User density profile

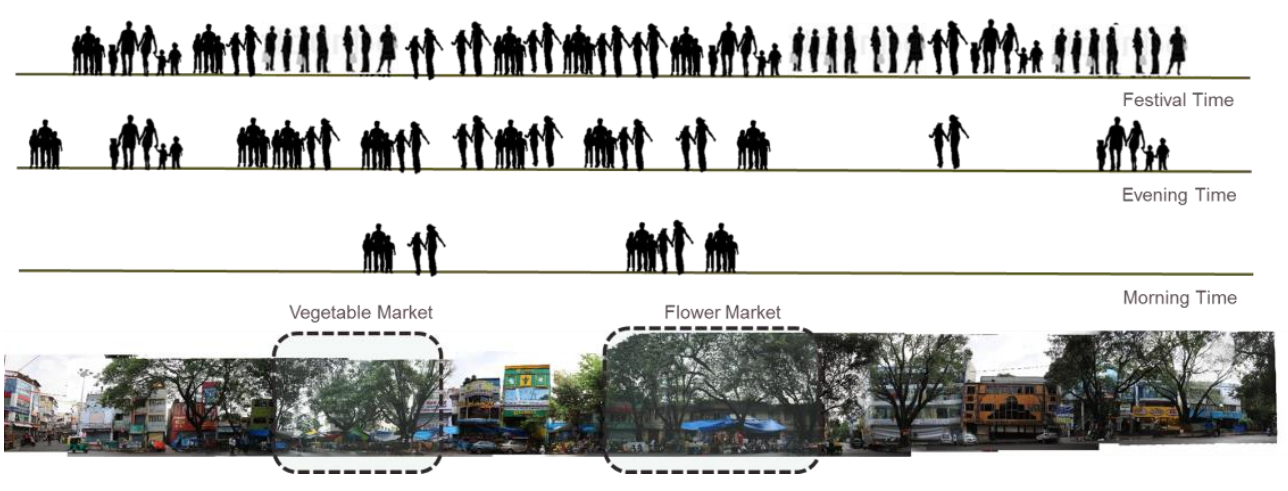

Source: Authors

Huge piles of unsegregated solid waste generated are dumped on the sidewalks further adding to the distresses of pedestrians and cyclists (Refer Fig. 43).

Fig. 43 Analysis of different types of waste generators

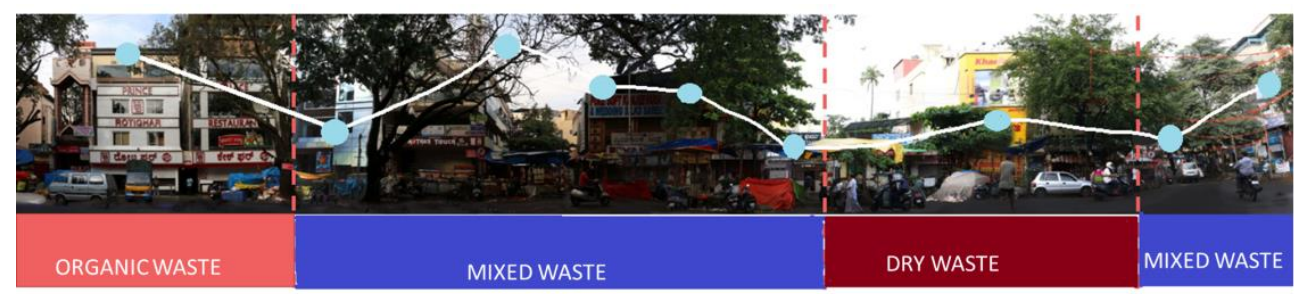

Source: Authors 
With increasing urban migration and the shrinking formal sector, hawking and street vending have emerged as one of the critical means of earning a livelihood for the urban poor in India. Street vending is an important activity related to informal sector in urban areas. As long as our urban roads are used by the various cross sections of inhabitants, street vendors will remain inevitable. Street vendors are the broadly defined as persons who offer goods and services for sale to the public without having a permanent built-up structure but with a temporary static structure or mobile stall with various area requirements (Refer Fig.44).

Fig. 44 Vendor typologies

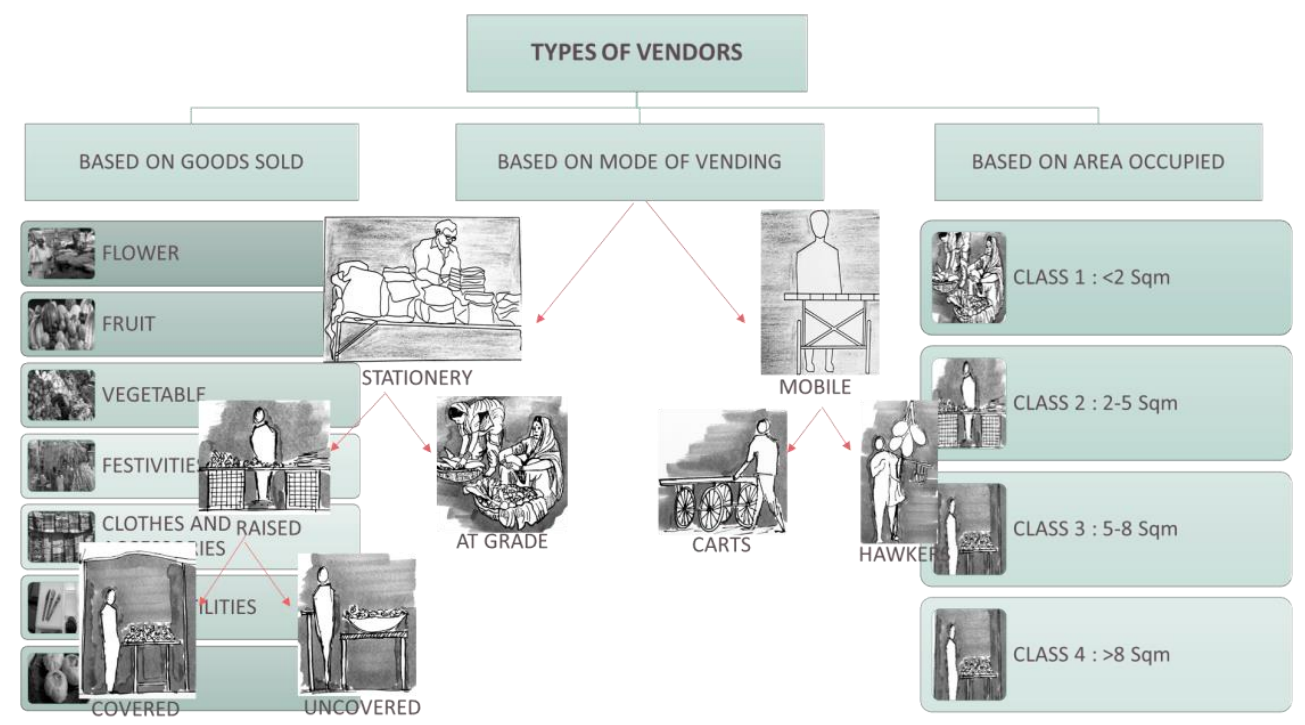

\section{Source: Authors}

Bicycles, pedestrians and bus traffic attract street vendors, often selling stuff which are in demand by road users. Vendors often locate themselves at places which are natural markets for them. A careful analysis of the location of vendors, their numbers at each location and the type of services provided clearly shows that they are needed since they work under completely 'free market' principles. If their services were not required at those locations, they would have no incentive to be there. (Refer Fig. 35, $36,37,38 \& 39)$.

Fig. 45 Mapping the locations of vendors

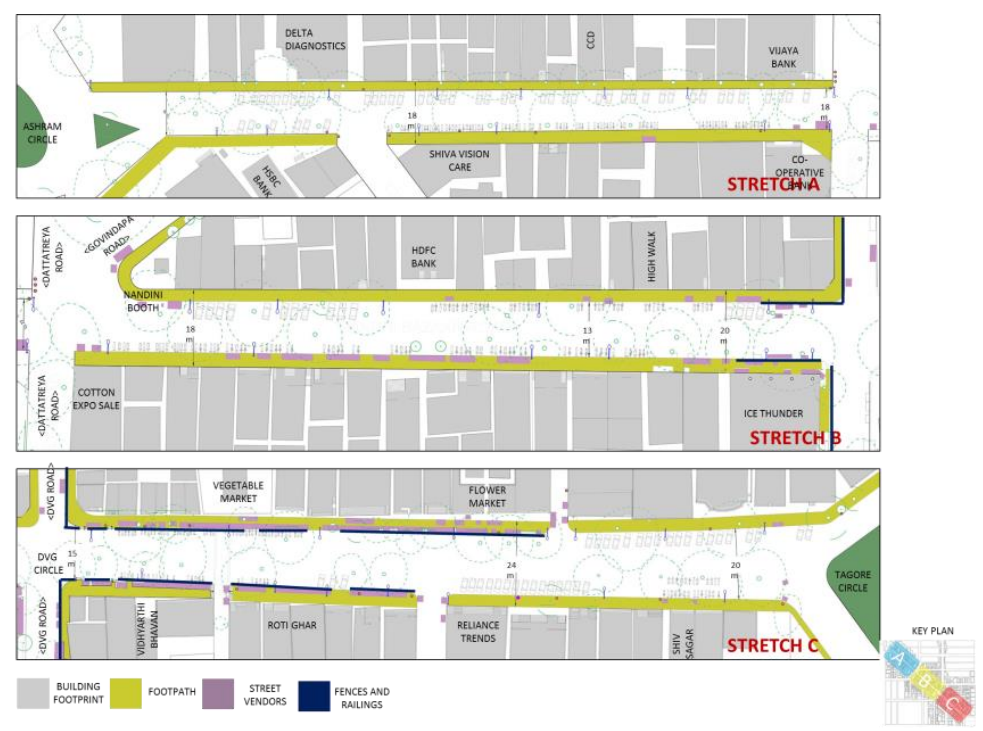

Source: Authors 
Fig. 46 Location of vendors and typologies

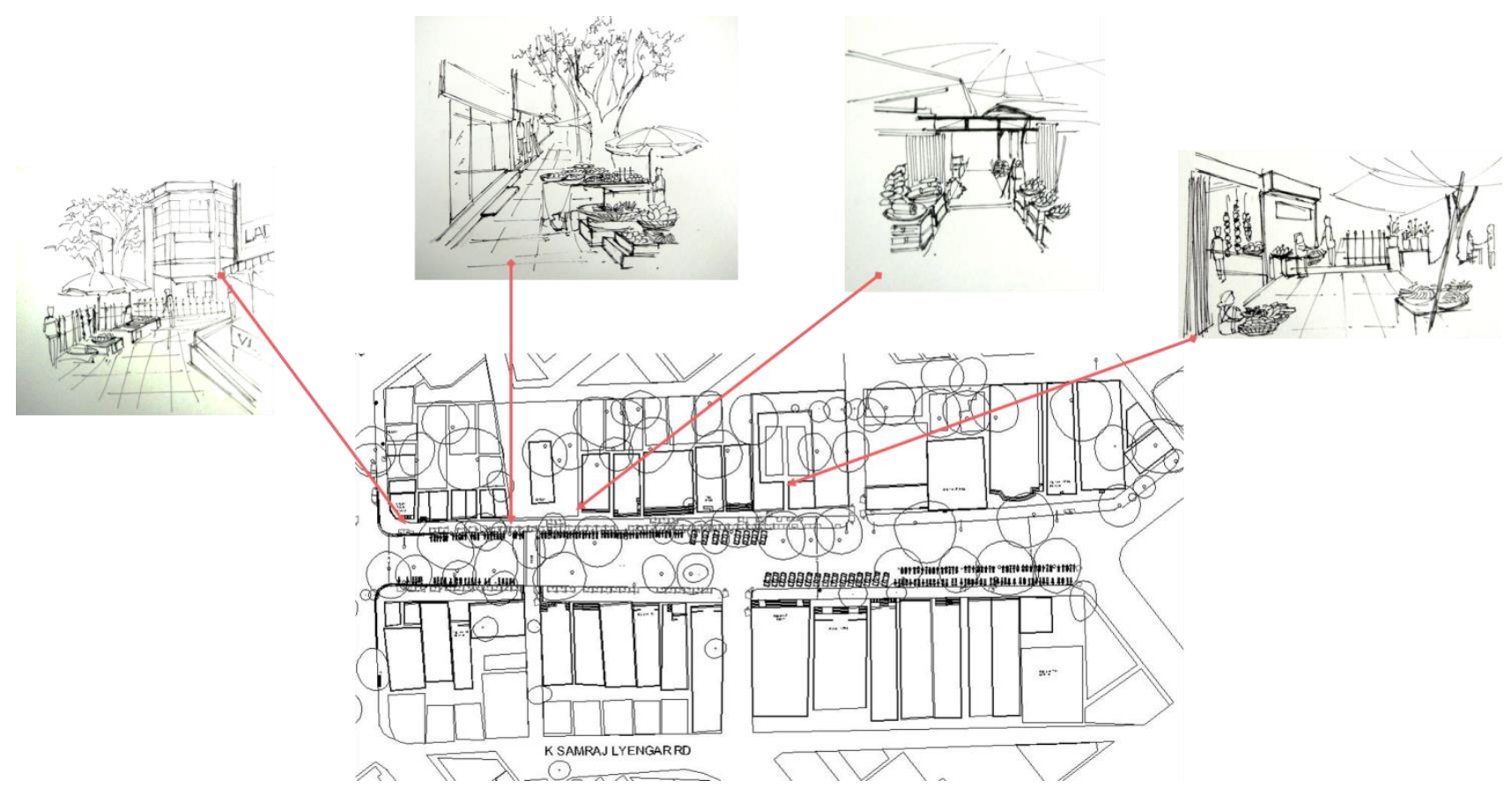

Source: Authors

Fig. 47 Part plan showing vending activities on footpath
Fig. 48 Section highlighting vending activities on footpath
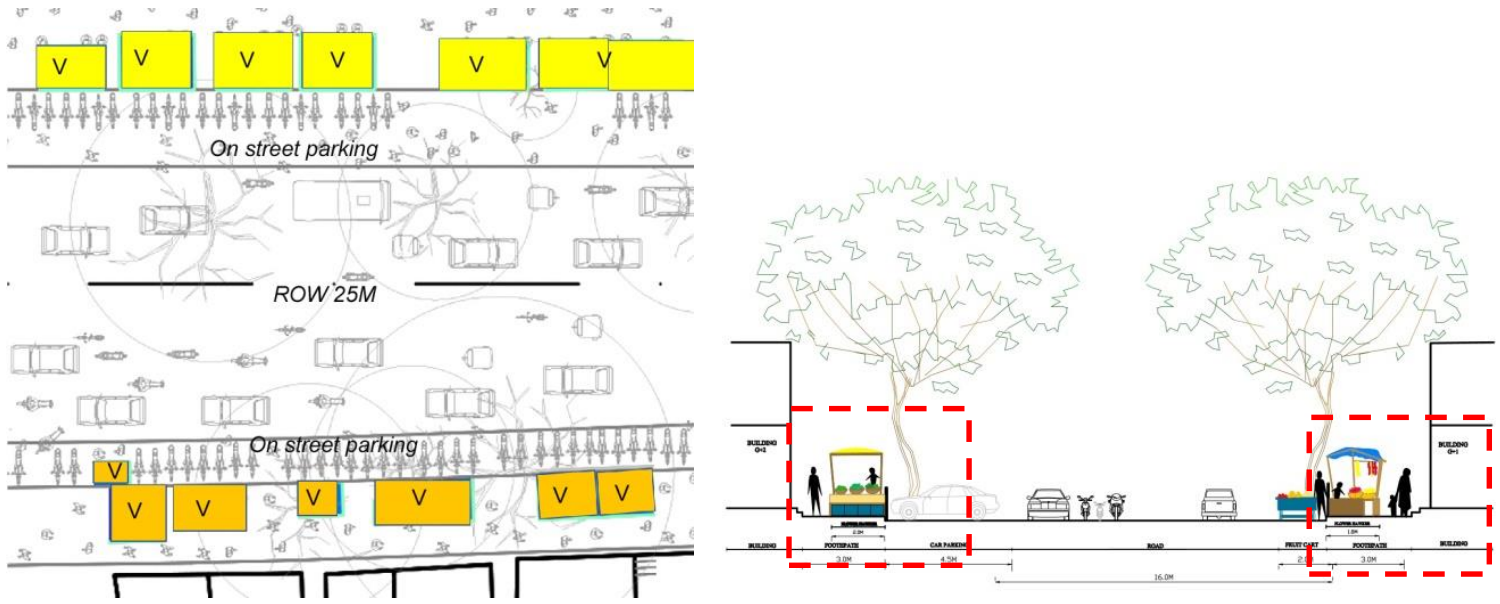

Source: Authors

The spatial arrangement of vending activities is organic and temporal in nature. The arbitrator location of the vendors leads to encroachment of pedestrian space on the footpath. Street vending provides many opportunities: goods and services at convenient locations, and affordable prices; self-employment for large numbers of people; links formal sector with consumers; keeps streets busy and safe, creates an interesting city environment.

Considering the detailed analysis of the Gandhi Bazaar area, inclusive street design (better use of existing space through optimum space management and time-sharing) can be proposed to generate resourceful use of space for diverse stakeholders. Subsequent section of the paper discusses the various aspects of inclusive street design. 


\section{Inclusive Streets for Mobility Solution: Schemes and design stratergies}

\subsection{Pedestrianization, Non-Motorised Transportation (NMT) and Public Transport}

Successful pedestrian zones are not only a matter of closing the streets to traffic, but are the creation and management of a safe and conducive urban environment.

\begin{tabular}{|c|c|c|}
\hline Environmental & Social & Economic \\
\hline $\begin{array}{l}\text { - } \begin{array}{l}\text { Improved urban } \\
\text { environment }\end{array} \\
\text { - Open space preservation - } \\
\text { increase in lung and buffer } \\
\text { areas }\end{array}$ & $\begin{array}{l}\text { - Improved public health } \\
\text { - } \\
\text { Improved opportunities to } \\
\text { - } \text { Improve cultural resources } \\
\text { people who are transport } \\
\text { disadvantaged }\end{array}$ & 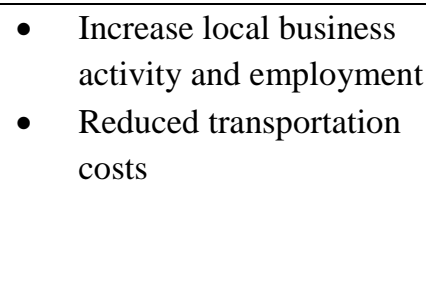 \\
\hline
\end{tabular}

Source: Authors

Fig.49 Proposed Non-Motorized Transportation Hub

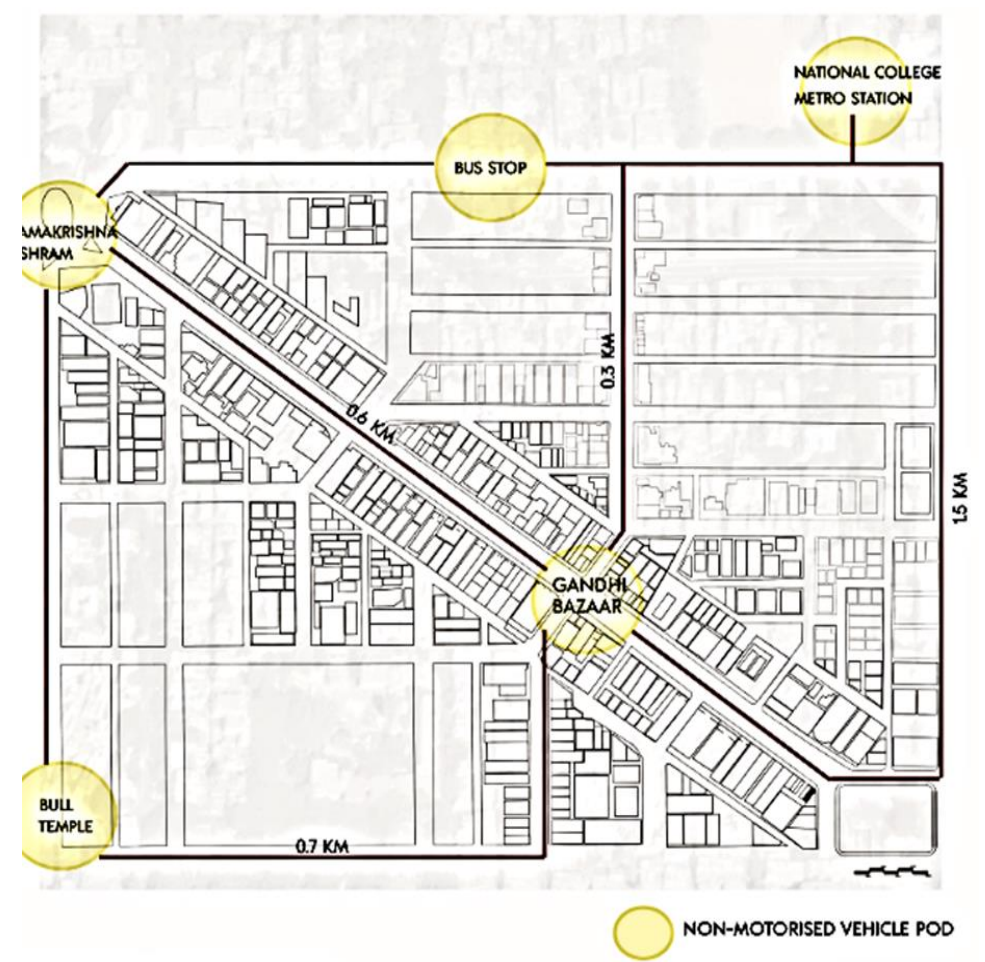

Source: Authors

Primary Streets important for Pedestrians and Vehicles are:

- DVG Road (15M wide)

- $\quad \mathrm{KR}$ Road (35M wide)

\section{Destinations / Trip Generators}

Several types of destinations and trip generators (majorly commercial centres) within the Gandhi Bazaar generate most pedestrian and vehicular traffic. 


\section{Parking}

Parking space has been provided for two wheelers and Cars at different segments of the road. But as this provision is highly insufficient, there exists some illegal parking of vehicles on certain stretches aggravating the situation.

\section{Recommendation by CTTP}

The Bangalore Comprehensive Traffic and Transportation Plan (CTTP) study has recommended Gandhi Bazaar Main Road as one of the three identified roads (other two roads being $10^{\text {th }}$ Main Road adjacent to Jayanagar Shopping Complex \& Russel Market Road) suitable for becoming pedestrian only roads.

Table 4. Temporal Pedestrianization Strategy

\begin{tabular}{|c|c|c|}
\hline FESTIVAL TIME & Complete Pedestrianization & $\begin{array}{c}\text { Prohibition of motorized traffic on all the days \& } \\
\text { at all times by means of formal traffic orders }\end{array}$ \\
\hline WEEKENDS & Part-time pedestrianization & $\begin{array}{c}\text { Prohibition of motorized traffic for only fixed } \\
\text { hours of the day and/or certain days of the week }\end{array}$ \\
\hline FULL TIME & Partial Pedestrianization & $\begin{array}{c}\text { Infrastructure for pedestrians / cyclists/ NMT } \\
\text { and Public transport }\end{array}$ \\
\hline
\end{tabular}

Source: Authors

Table 5. Implementing mechanism: Pedestrianization, NMT and Public Transport

\begin{tabular}{|c|c|c|}
\hline Description & $\begin{array}{l}\text { Implementing Board / } \\
\text { Committee }\end{array}$ & \& Regulatory \\
\hline $\begin{array}{l}\text { All vehicular traffic should be diverted } \\
\text { around periphery of Gandhi Bazaar, that } \\
\text { is, Tagore circle - KR Road - Vani Vilas } \\
\text { Road - North Road through Gandhi } \\
\text { Bazaar via Girls School Road - National } \\
\text { Co-operative Bank to Vivekananda circle. } \\
\text { Only uni-directional flow should be } \\
\text { allowed. }\end{array}$ & $\begin{array}{l}\text { A ward level } \\
\text { structuring committee } \\
\text { should be formed having } \\
\text { adequate representation of } \\
\text { various stakeholders and } \\
\text { civil society groups at } \\
\text { ward \& city level. }\end{array}$ & $\begin{array}{l}\text { Municipalities and ULBs shall } \\
\text { be entrusted with seed funding. } \\
\text { Subsequently, revenue generated } \\
\text { from NMT Hubs and vendor } \\
\text { licensing should support the } \\
\text { implementation. }\end{array}$ \\
\hline
\end{tabular}

Source: Authors

\section{NMT (Non-motorized Transport) Hub}

Public transport has been integrated with pedestrian/cycling network through NMT Hub. These NMT Hubs provide the following facilities and advantages:

- Shuttle service pod between metro stations, major bus stops, transit nodes, etc.

- Better accessibility and connectivity of footpaths/cycle paths with transit stops augmenting safe and faster commuting.

- Pedestrian /cycle facilities like secure bike parking, information regarding bus schedules / routes shall be developed using ICT interface.

- NMT hubs act as counters for small scale visitor / tourist information centre, renting bicycles / electric vehicles, various types of ticket booking, utility bill payments, etc.

- Small scale conveniences / amenities to foster community interactions crafting public space 


\subsection{Solid Waste Management}

Solid waste management is a major issue and the situation aggravates during festival seasons and special occasions. Most of the vendors dump their waste either on footpath or in front of the shops or road leading to unhygienic conditions.

Table 6: Implementing Mechanism: Solid Waste Management

\begin{tabular}{|c|c|c|}
\hline Description & $\begin{array}{c}\text { Implementing Board / } \\
\text { Committee }\end{array}$ & Funding \& Regulatory framework \\
\hline $\begin{array}{l}\text { - Awareness programs regarding } \\
\text { segregation at the source. } \\
\text { - Segregation \& collection points } \\
\text { at strategic locations. } \\
\text { - Stark monitory penalties for } \\
\text { defaulters. }\end{array}$ & $\begin{array}{l}\text { Gandhi Bazaar } \\
\text { Welfare Association } \\
\text { should be formed to } \\
\text { create awareness } \\
\text { among different } \\
\text { stake holders }\end{array}$ & $\begin{array}{l}\text { Municipalities and ULBs shall } \\
\text { be entrusted with seed funding. } \\
\text { Subsequently, revenue generated } \\
\text { from NMT Hubs and vendor } \\
\text { licencing should support the } \\
\text { implementation and maintenance. }\end{array}$ \\
\hline
\end{tabular}

Source:Authors

\subsection{Vendors and Informal Sector}

Mapping the existing situation

In Gandhi Bazaar, vendors operate on regular basis. There are no associations or registered groups for vendors. Through informal arrangements, a specific area within the market is designated for individual vendors. During festivities, the number of vendors reaches 200.

Table 22. Number of vendors on Gandhi bazaar Main road by category:

\begin{tabular}{|c|c|c|c|c|}
\hline Fruit vendors & Vegetable Vendors & Flower vendors & Other vendors & Total \\
\hline 28 & 35 & 40 & 64 & 167 \\
\hline
\end{tabular}

Structural condition and duration of work:

More than half of the hawking units are mobile in nature while one third units are stationary and very few come under others category. One third of the vendors are selling their goods on sitting ground with sheet, handcart becomes second and kiosk or stalls are the third option.

The unit size of $11 \%$ vendors is less than 10 sq. $\mathrm{ft}$. Almost half of the vendors occupied 10 to 40 sq. ft. space for their stall. Majority of vendors are working whole day while some vendors work only during the evenings or morning hours.

Locational characteristics, problems being faced by vendors $\&$ their future prospects:

Almost $40 \%$ vendors believe established market as important factor for vending whereas one fifth vendors believe both, high residential density and established market place and some of them believe that only high residential density as a major factor for creating demand. Large number of vendors reported festival and one third of vendors reported weather as important factor whereas some vendor has reported other reasons. Here, only $3 \%$ of vendors are member of any vendor organization. Half of the vendors reported that they are facing problems to continue doing business. Out of half of vendors one third facing problem of harassment by authorities, one third facing problem of eviction and few of them are facing problem of conflict with pedestrians, confiscation of goods and extortion by authority. In all, three fourth of the total vendors do not agree to relocate from original place whereas one fifth of the vendors agreed only if they are shifted to nearby places and their requirements are taken care in new location.

National Policy on Urban Street Vendor:

In 2004, first time, Government of India through National Policy on Urban Street Vendor recognized that urban vending is not only a source of employment but provides 'affordable' services to the majority of urban population. Model Street Vendors (Protection of Livelihood and Regulation of Street Vending) Bill, 2009 are some of the initiatives taken by the Government. 


\section{$\underline{\text { Creating space for vendor zones within existing infrastructure by efficient design }}$}

The strategy of the suggested model is to categorize markets into three broad categories and to then give design proposals for each. The Markets are categorized into:

a. Markets along the Street

b. Organized Vendor zones, which have a separate, designated space for vendors to operate. This space is taken to be off-street.

c. Flexible Vending Zones which are used for different purposes at different times of the day.

Fig.50, 51 \& 52 Different vending zones within the existing infrastructure

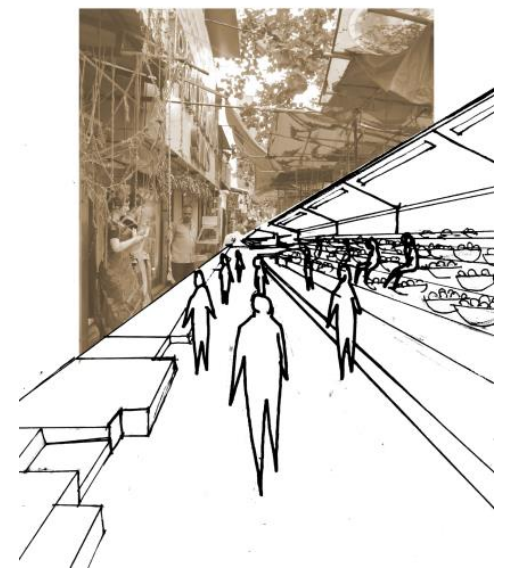

Permanent vendor modules with defined edges and boundaries so that there is no interference with public movement.

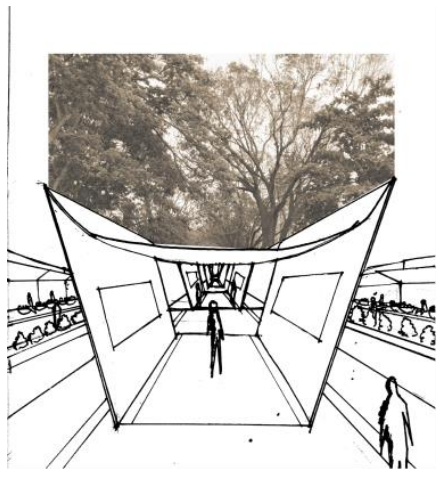

Setting up temporary art exhibitions when the road is pedestrianized during the day

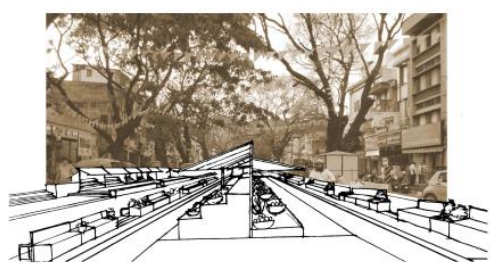

During festivals the street shall be completely pedestrianized creating more space for temporal vendors and cultural activities.

Source: Authors

The following implementation mechanism and provisions for inclusion of street vending have been given under the preview of Nation Policy on Urban street Vendors

Table 10: Implementing Mechanism: Vendors and Informal Sector

\begin{tabular}{|c|c|c|}
\hline Description & $\begin{array}{c}\text { Implementing } \\
\text { Board / } \\
\text { Committee }\end{array}$ & Funding \& Regulatory framework \\
\hline $\begin{array}{l}\text { A) Spatial management of vending areas } \\
\text { through: } \\
\text { - Creating space for vendor zones } \\
\text { within existing infrastructure by } \\
\text { efficient design. } \\
\text { - Usage of incidental space to the } \\
\text { advantage. } \\
\text { - Time sharing of space. } \\
\text { B) Provision of proper hawking space to } \\
\text { avoid conflict with customers - The } \\
\text { National Policy stresses on demarcation of } \\
\text { "Hawking" and "No- Hawking Zones". } \\
\text { Designation and provision of vendors } \\
\text { market/ no vending zones should be } \\
\text { undertaken by the participatory process } \\
\text { meanwhile considering relocation or }\end{array}$ & $\begin{array}{l}\text { City level } \\
\text { advisory body } \\
\text { should be } \\
\text { formed having } \\
\text { adequate } \\
\text { representation } \\
\text { of the vendors } \\
\text { and other civil } \\
\text { society groups. }\end{array}$ & $\begin{array}{l}\text { I) Issuing License (mentioning space and } \\
\text { time specific) \& photo ID cards (mentioning } \\
\text { activity type, location of vending space } \\
\text { along with bio- data) against payment of } \\
\text { charges to enhance the revenue of ULBs. A } \\
\text { part of this revenue could be used for } \\
\text { provision of basic infrastructure such as } \\
\text { drinking water, toilets and waste collection } \\
\text { and temporary or permanent structure for } \\
\text { vendors. } \\
\text { II) Only one hawking license per family } \\
\text { should be issued for a fixed per month } \\
\text { payable in advance. The license may be } \\
\text { renewed at the discretion of the } \\
\text { commissioner. } \\
\text { III) Improving economic status of hawkers: }\end{array}$ \\
\hline
\end{tabular}


accommodation of vendors.

C) Integration of street vendors: The average size of vending unit is $2.3 \mathrm{SqM}$.

Almost $73 \%$ of the space is being used by vendors against movement space for customers and other activities. If the natural markets will be regularized in a planned manner, the movement space and area occupied by vendors will be reduced that will ultimately reduce the area of the entire market.

C) Integration of hawking units with organized retail spaces in their present location itself. A minimum distance of $2.0 \mathrm{M}$ (for 4 pedestrians to sufficiently pass through) must be maintained between a formal shop and a hawking space. Hawking space and formal shops selling similar type of goods must be kept at distant from each other to avoid conflicts.

D) The design of the public squares and spaces can be done in a manner so as to accommodate the hawkers and the street vendors in the design itself integrating the visual context into the image of the urban fabric.

Source: Authors

\section{Way Forward}

Shared value of a street is maximized when urban inhabitants of all ages and diverse abilities (socio-economical and physical) are not only able to access but also play a pivotal role in its conception, conservation and identity. Street's public space aspect needs to be supplemented by addressing the ever evolving needs of the inhabitants. Detailed analysis and the proposed strategies provide inclusive interactions promoting the enhanced usage of Gandhi Bazaar road as the public space. With shrinking public spaces in urban areas, streets like Gandhi Bazaar if developed as inclusive streets could lead to enhanced sociability and community interactions. An inclusive street connects communities, successfully made up of holistic neighborhoods with engaging places. Concept and strategies of inclusive streets can be progressively implemented through better planning, design, due considerations for vital aspects of the streets and active community participation. 


\section{References}

[1] Abbey, N., \& Butten, D. (1997). Safer cities and towns: A guide to developing strategic partnerships. Melbourne, Australia: Department of Justice.

[2] Ashton, P. (1993). The accidental city: Planning Sydney since 1788. Sydney: Hale \& Ironmonger.

[3] "Court Street Square-A New Heart for Downtown." Main Street (San Bernardino, California). Spring 1994.

[4] Issar, T.P., The City Beautiful, Bangalore Urban Arts Commission, 1998, Bombay.

[5] Krier, Rob, Urban Space, Academy Editions, London, 1979.

[6] Prakasarao, V.L.S. and Tewari, V.K., The Structure of an Indian Metropolis: A Study of Bangalore.

[7] Report of Bangalore Development Committee, Government of Mysore, Bangalore, 1954.

[8] City of Port Phillip (1996). Annual Report 95/96. St Kilda, Australia: Author.

[9] Municipal Land Use Center at The College of New Jersey. "New Jersey Department of Transportation Highway Corridor Demonstration Projects: A Summary Report of Participant

[10] Nair, Janaki, "Battles for Bangalore: Re-territorialising the city", Centre for Study of Culture and Society, Bangalore.

[11] Dutta, Arindam, "Politics of Space", Architecture + Design, March-April 1999.

[12] Ribeiro, E.F.N., "From Mud Fort to Metropolitan Region", Architecture + Design, March-April 1999.

[13] Congress for the New Urbanism (1999b). Congress for the New Urbanism [on-line]. Available: http://www.cnu.org/ (Accessed 16/07/2018).

[14] Congress for the New Urbanism (1999c). CNU and its current initiatives [online].Available:http://www.cnu.org/moreabout.html (Accessed 11/08/2018).

[15] "Re-imagining public spaces in cities":http://infochangeindia.org/environment/ecologic/reimagining- public-spaces-in-cities.html 